\title{
Avaliação dos achados clínicos e histopatológicos nas lesões de poiquilodermia de Civatte antes e após o tratamento com luz intensa pulsada
}

Dissertação apresentada à Faculdade de Medicina da Universidade de São Paulo para obtenção do título de Mestre em Ciências

Área de concentração: Dermatologia Orientador: Prof. Dr. Luis Carlos Cucé

São Paulo 2005 


\section{TATIANA BASSO BIASI}

\section{Avaliação dos achados clínicos e histopatológicos nas lesões de poiquilodermia de Civatte antes e após o tratamento com luz intensa pulsada}

Dissertação apresentada à Faculdade de Medicina da Universidade de São Paulo para obtenção do título de Mestre em Ciências

Área de concentração: Dermatologia

Orientador: Prof. Dr. Luis Carlos Cucé

São Paulo

2005 


\section{AGRADECIMENTOS}

Ao Prof. Dr. Luis Carlos Cucé, orientador que abriu as portas da UNISA para a realização do terceiro ano de residência em dermatologia e possibilitou a realização deste mestrado.

À Dra. Roosecelis Araújo Brasil, amiga que passou comigo várias horas dos seus finais de semana na Faculdade de Medicina da USP e que muito me auxiliou na leitura das lâminas e na dissertação. Sua ajuda foi preciosa!

Às Profas. Dras. Neusa Sakai Valente e Mirian Nacagami Sotto, pela paciência e boa vontade em ensinar nas várias vezes em que busquei auxílio.

Aos Profs. Drs. Neil Ferreira Novo e Yara Juliano, pelo recebimento carinhoso, pela disponibilidade constante e pela orientação na análise estatística.

À Profa. Dra. Marisa Dohlnikoff, por ter ensinado o método de morfometria com análise de imagens por computador e por ter permitido a utilização dos equipamentos do Laboratório de Poluição da FMUSP para a sua realização.

Ao Dr. Luiz Fernando Ferraz da Silva, pela solicitude todas as vezes em que precisei de sua ajuda.

À Dra. Gabriella Di Giunta, amiga que apoiou e auxiliou na correção do trabalho.

À Dra. Áurea Lopes, pelas orientações em relação à utilização do aparelho Quantum. 
À Profa. Dra. Marina Emiko Yagima Odo e sua equipe, que além de ser um exemplo de profissional a ser seguido, gentilmente permitiu a utilização do aparelho Quantum e de toda a estrutura de sua clínica.

À Profa. Dra. Bhertha Miyuki Tamura, incentivadora da minha ida à São Paulo.

Aos residentes de dermatologia da UNISA e da FMUSP e aos colegas do Ambulatório de Inestética do Departamento de Dermatologia do HCFMUSP, que gentilmente selecionaram e encaminharam pacientes para participarem do estudo.

Aos amigos do Laboratório da Disciplina de Patologia de Moléstias Transmisíveis da FMUSP, sempre carinhosos e solícitos.

Aos funcionários do Laboratório de Poluição da FMUSP Ana Luiza Barreiros e Reginaldo do Nascimento, pela prestatividade e boa vontade constantes.

À equipe técnica do Laboratório de Histopatologia do Departamento de Dermatologia do HC-FMUSP, pelo cuidado e organização no preparo do material histopatológico.

A todos os integrantes do Departamento de Dermatologia do Hospital das Clínicas da Faculdade de Medicina da Universidade de São Paulo, que possibilitam a realização de trabalhos como este e ao Prof. Dr. Evandro Ararigboia Rivitti, que viabilizou este estudo no seu aspecto financeiro.

Ao Cleiton Alves, pela realização da técnica imunohistoquímica deste trabalho. 
Aos fotógrafos Rogério Voltar e Frederico Vasconcelos, pelos ensinamentos que foram úteis na realização dos registros fotográficos dos pacientes.

À Valéria Vilhena e Sônia Toledo Carvalho, pelas orientações em relação às referências bibliográficas e à confecção da ficha catalográfica do trabalho.

Aos pacientes, sem os quais não teria sido possível a realização deste trabalho.

A todos os meus amigos; aos que tiveram participação direta em alguma parte deste trabalho, como Vitor Lima, Daniel Lorenzini, Ana Carolina Handel, Karine Piñera, Eliane Cardoso dos Reis, Natalia Cymrot Cymbalista, Patrícia Biasi Cavalcanti, Maria Aparecida José Basso, Luiz Fernando Vaz Teixeira, Karina Streliaev Dziekaniak, Maurício Amboni Conti, Silvana Francesca de Souza Moreira, Luciana Pessoli Buffon Leal; e aos que participaram de forma indireta, ao ouvir, apoiar e estimular... Muito obrigada!

Ao querido Alexandre, pelo apoio que sei que posso contar.

À minha família, sempre presente participando e apoiando as minhas decisões... Em particular ao meu pai, que cuidadosamente e com muito carinho fez a revisão da língua portuguesa da dissertação. Não há como descrever a importância de vocês nesta jornada...

A todas as pessoas que, de alguma forma, tiveram participação direta ou indireta nesta conquista. 
"Uma vez que uma técnica ou instrumento é trazido à atenção do público através dos jornais, televisão, rádio, revistas femininas ou outras formas de propaganda, a avaliação científica está acabada e a corrida está acontecendo... A forma mais rápida de forçar a aceitação de uma técnica ou instrumento médico é convencer o público, o qual por sua vez convence os médicos, os quais exigem aprovação e uso. Novamente, a lógica é 'Se eu não fizer isto, alguém fará...'. Este é o novo método científico na medicina."

Rox Anderson, 1985. 
Esta dissertação está de acordo com:

Referências: adaptado de International Committee of Medical Journals Editors (Vancouver)

Universidade de São Paulo. Faculdade de Medicina. Serviço de Biblioteca e Documentação. Guia de apresentação de dissertações, teses e monografias. Elaborado por Anneliese Carneiro da Cunha, Maria Júlia de A. L. Freddi, Maria F. Crestana, Marinalva de Souza Aragão, Suely Campos Cardoso, Valéria Vilhena. São Paulo: Serviço de Biblioteca e Documentação; 2004.

Abreviatura dos títulos dos periódicos de acordo com List of Journals Indexed in Index Medicus. 


\section{SUMÁRIO}

\begin{tabular}{|c|c|}
\hline \\
\hline & \\
\hline 中 & $\begin{array}{c}X \\
x i i\end{array}$ \\
\hline Resumo & xiii \\
\hline (1) & xiv \\
\hline
\end{tabular}

1. INTRODUÇÃO........................................................................... 1

1.1. Definição................................................................. 1

1.2. Sinonímia............................................................. 2

1.3. Aspectos históricos............................................................. 2

1.4. Classificações....................................................................... 7

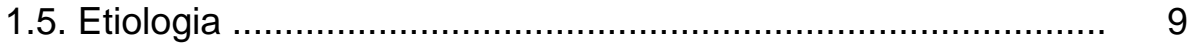

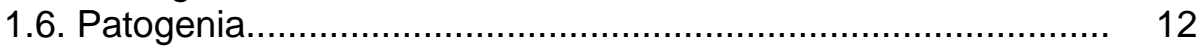

1.7. Histopatologia................................................................. 13

1.8. Importância clínica............................................................. 14

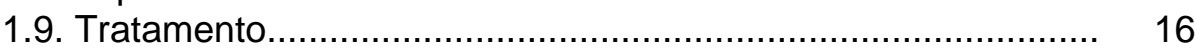

1.9.1. Tratamento da poiquilodermia de Civatte com LASER.... 18

1.9.2. Luz intensa pulsada..................................................... 20

1.9.3. Tratamento da poiquilodermia de Civatte com luz intensa pulsada.................................................................. 22

1.9.4. Modificações histopatológicas após a utilização da luz intensa pulsada................................................................ 24

2. OBJETIVOS............................................................................... 27

3. CASUÍSTICA E MÉTODO........................................................ 28

3.1. Casuística........................................................................ 28

3.2. Critérios de inclusão, exclusão e suspensão do paciente da pesquisa............................................................................ 29

3.3. Coleta do material fotográfico e biópsias................................ 29

3.4. Tratamento.................................................................... $\quad 30$

3.5. Acompanhamento pós-pesquisa............................................ 33

3.6. Critérios de avaliação clínica................................................. 34

3.6.1. Avaliação dos resultados............................................... 34

3.6.2. Avaliação dos efeitos colaterais.................................. 35

3.7. Critérios de avaliação histopatológica...................................... 36

3.7.1. Coloração pela hematoxilina e eosina.......................... 36

3.7.2. Método de morfometria com análise de imagens por computador.

3.7.3. Coloração para fibras elásticas.................................... 38

3.7.4. Coloração para pigmento melânico............................... 41

3.7.5. Técnica imunohistoquímica......................................... 43

3.7.6. Análise dos vasos.................................................... 44 
3.8. Método estatístico.

página

46

4. RESULTADOS............................................................................... 47

4.1. Dados epidemiológicos..................................................... 47

4.2. Dados clínicos........................................................................ 47

4.2.1. Avaliação fotográfica dos resultados............................ 48

4.2.2. Avaliação dos efeitos colaterais................................... 52

4.3. Dados histopatológicos....................................................... 54

4.3.1. Coloração pela hematoxilina e eosina........................... 54

4.3.2. Coloração pelo Weigert com oxidação.......................... 55

4.3.3. Coloração pelo Fontana Masson.................................. $\quad 55$

4.3.4. Marcação imunohistoquímica com o anticorpo anti-CD34.................................................................... 56

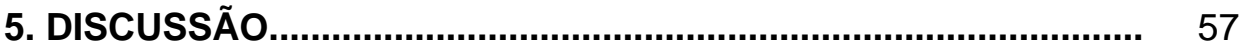

6. CONCLUSÕES ......................................................................... 70

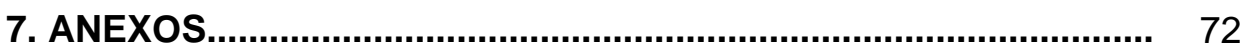

ANEXO A - Termo de consentimento ....................................... 72

ANEXO B - Entrevista ....................................................... 77

ANEXO C - Orientações para a análise das fotografias................... 78

ANEXO D - Tabelas estatísticas.................................................. 80

8. REFERÊNCIAS BIBLIOGRÁFICAS............................................ 90 


\section{LISTA DE ABREVIATURAS}

$\begin{array}{ll}\mu \mathrm{m} & \text { micrômetros } \\ \mathrm{cm}^{2} & \text { centímetros quadrados } \\ \text { DEM } & \text { dose eritematosa mínima } \\ \mathrm{HE} & \text { hematoxilina e eosina } \\ \mathrm{J} & \text { joules } \\ \mathrm{KTP} & \text { potássio titanil fosfato } \\ \text { LCP } & \text { LASER de corante pulsado } \\ \text { LIP } & \text { luz intensa pulsada } \\ \mathrm{mm} & \text { milímetros } \\ \mathrm{ms} & \text { milisegundos } \\ \mathrm{nm} & \text { nanômetros } \\ \text { PC } & \text { poiquilodermia da Civatte } \\ \text { TRT } & \text { tempo de relaxamento térmico }\end{array}$




\section{LISTA DE TABELAS}

Tabela 1 Avaliação da resposta clínica do componente vascular da poiquilodermia de Civatte, através das fotografias antes e após o tratamento com luz intensa pulsada, realizada por cinco observadores.

Tabela 2 Avaliação da resposta clínica do componente pigmentar da poiquilodermia de Civatte, através das fotografias antes e após o tratamento com luz intensa pulsada, realizada por cinco observadores.

Tabela 3 Porcentagem de casos de poiquilodermia de Civatte tratados com luz intensa pulsada, segundo escores de resposta clínica dos componentes vascular e pigmentar, avaliados por cinco observadores a partir das fotografias de 15 pacientes.......................

Tabela 4 Efeitos colaterais e tempo médio para resolução em dias, nos 15 pacientes portadores de poiquilodermia de Civatte na região cervical tratados com luz intensa pulsada, observados em pelo menos uma das cinco sessões.

Tabela $5 \quad$ Escores de resposta clínica dos componentes pigmentar e vascular das lesões de poiquilodermia de Civatte tratadas com luz intensa pulsada, avaliados por cinco observadores a partir das fotografias de 15 pacientes.

Tabela $6 \quad$ Indivíduos portadores de poiquilodermia de Civatte submetidos ao tratamento com luz intensa pulsada, segundo a presença de hiperceratose na coloração por hematoxilina e eosina, nos períodos pré e pós-tratamento.

Indivíduos portadores de poiquilodermia de Civatte submetidos ao tratamento com luz intensa pulsada, segundo a presença de retificação da epiderme na coloração por hematoxilina e eosina, nos períodos pré e pós-tratamento.

Tabela 8 Indivíduos portadores de poiquilodermia de Civatte submetidos ao tratamento com luz intensa pulsada, segundo a presença de degeneração hidrópica dos queratinócitos basais na coloração por hematoxilina e eosina, nos períodos pré e pós-tratamento.

Tabela 9 Indivíduos portadores de poiquilodermia de Civatte submetidos ao tratamento com luz intensa pulsada, segundo a presença de zona grenz na coloração por hematoxilina e eosina, nos períodos pré e pós-tratamento.

Tabela 10 Indivíduos portadores de poiquilodermia de Civatte submetidos ao tratamento com luz intensa pulsada, segundo a presença de proliferação vascular na coloração por hematoxilina e eosina, nos períodos pré e pós-tratamento. 

tratamento com luz intensa pulsada, segundo a presença de hiperplasia das glândulas sebáceas na coloração por hematoxilina e eosina, nos períodos pré e pós-tratamento

Tabela 12 Indivíduos portadores de poiquilodermia de Civatte submetidos ao tratamento com luz intensa pulsada, segundo a intensidade da degeneração basofílica do tecido conjuntivo na coloração por hematoxilina e eosina, nos períodos pré e pós-tratamento.

Tabela 13 Indivíduos portadores de poiquilodermia de Civatte submetidos ao tratamento com luz intensa pulsada, segundo a intensidade do infiltrado inflamatório na coloração por hematoxilina e eosina, nos períodos pré e pós-tratamento

Tabela 14 Indivíduos portadores de poiquilodermia de Civatte submetidos ao tratamento com luz intensa pulsada, segundo os valores da área de fibras elásticas coradas pelo Weigert com oxidação, em relação à área total medida, na derme superficial e profunda, nos períodos pré e pós-tratamento. Valores das diferenças percentuais $(\Delta \%)$ calculados a partir dos dois períodos.

Tabela 15 Indivíduos portadores de poiquilodermia de Civatte submetidos ao tratamento com luz intensa pulsada, segundo os valores da área com pigmento melânico coradas pelo Fontana Masson em relação à área total medida, na epiderme e derme justa-epidérmica, nos períodos pré e pós-tratamento. Valores das diferenças percentuais $(\Delta \%)$ calculados a partir dos dois períodos......

Tabela 16 Indivíduos portadores de poiquilodermia de Civatte submetidos ao tratamento com luz intensa pulsada, segundo os valores da área com pigmento melânico coradas pelo Fontana Masson em relação à área total medida, na epiderme e derme justa-epidérmica, nos períodos pré e pós-tratamento, excluídos dois casos com valores discrepantes. Valores das diferenças percentuais $(\Delta \%)$ calculados a partir dos dois períodos.

Tabela 17 Indivíduos portadores de poiquilodermia de Civatte submetidos ao tratamento com luz intensa pulsada, segundo os valores do número de vasos marcados pelo anti-CD34 na derme superficial e profunda, nos períodos pré e pós-tratamento. Valores das diferenças percentuais $(\Delta \%)$ calculados a partir dos dois períodos.

Tabela 18 Indivíduos portadores de poiquilodermia de Civatte submetidos ao tratamento com luz intensa pulsada, segundo os valores da média da área do lúmen dos vasos marcados pelo anti-CD34 na derme superficial e profunda, nos períodos pré e pós-tratamento. Valores das diferenças percentuais $(\Delta \%)$ calculados a partir dos dois períodos. 


\section{LISTA DE FIGURAS}

Figura 1 Curvas de absorção dos cromóforos oxihemoglobina, melanina e página água de acordo com a variação do comprimento de onda.

Figura 2 A: Aparelho IPL Quantum SR/HR®. B: Monitor do aparelho.

Figura 3 Aplicação da luz intensa pulsada.

Figura 4 A: Fibras elásticas coradas pelo Weigert com oxidação. Área de derme a ser medida selecionada com traço verde; B: Fibras elásticas marcadas em vermelho; C: Área total de derme selecionada marcada em vermelho.

Figura 5 A: Pigmento melânico corado pelo Fontana Masson. Área de epiderme a ser medida selecionada com traço verde; B: Pigmento melânico marcado em vermelho; C: Área total de epiderme selecionada marcada em vermelho.

Figura 6 A: Marcação imunohistoquímica do endotélio vascular com anticorpo anti-CD34; B: Lúmen do vaso marcado para cálculo da área.

Figura 7 A: Paciente com poiquilodermia de Civatte na região cervical antes do tratamento com luz intensa pulsada; B: Após 2 sessões; C: Após 4 sessões; D: Após 5 sessões.

Figura $8 \quad$ Efeitos colaterais observados após a utilização da luz intensa pulsada para o tratamento da poiquilodermia de Civatte na região cervical A: Eritema, edema e púrpura; B: Crostas; C: Persistência de áreas lineares não tratadas; D: Hiperpigmentação pós-inflamatória.. 


\section{RESUMO}

Biasi TB. Avaliação dos achados clínicos e histopatológicos nas lesões de poiquilodermia de Civatte antes e após o tratamento com luz intensa pulsada [tese]. São Paulo: Faculdade de Medicina, Universidade de São Paulo; 2005.

A poiquilodermia de Civatte é uma condição caracterizada por hiperpigmentação, telangiectasia e atrofia que acomete predominantemente - pescoço e a face de forma simétrica, poupando a área encoberta pelo mento. A sua ocorrência é associada à predisposição genética, à exposição cumulativa ao sol, ao processo de envelhecimento, à hipersensibilidade de contato e a fatores hormonais. Os tratamentos atualmente preconizados baseiam-se na utilização de sistemas de luzes que atuam através do princípio da fototermólise seletiva, isto é, dano térmico confinado a alvos específicos no tecido. Estudos clínicos mostram bons resultados no tratamento da poiquilodermia de Civatte com a luz intensa pulsada, porém não descrevem se estes resultados são acompanhados por alterações histopatológicas correspondentes. O objetivo deste estudo foi avaliar os achados clínicos e histopatológicos nas lesões de poiquilodermia de Civatte, antes e após o tratamento com a luz intensa pulsada. $O$ estudo avaliou 16 pacientes portadores de poiquilodermia de Civatte na região cervical, submetidos a 5 sessões mensais de aplicação de luz intensa pulsada, utilizando-se o filtro de $560 \mathrm{~nm}$. Os pacientes foram fotografados e biopsiados antes do tratamento e 30 dias após o término da quinta sessão. A avaliação clínica foi feita através da comparação das fotografias por 5 avaliadores independentes. Os resultados mostraram que o componente vascular responde melhor do que o componente pigmentar ao tratamento. A avaliação histopatológica foi feita de forma cega em relação aos cortes pré e pós-tratamento, sendo ao final das leituras revelados e comparados. Após cinco sessões não houve diferença na densidade das fibras elásticas na derme superficial e profunda. Não houve redução no número de vasos e na média da área do lúmem dos vasos marcados pelo anticorpo anti-CD34 na derme superficial e profunda. A quantificação do pigmento melânico mostrou redução significante na epiderme, porém não na derme. 


\section{SUMMARY}

Biasi TB. An evaluation of the clinical and histopathological findings of the lesions of poikiloderma of Civatte before and after treatment with intense pulsed light [thesis]. São Paulo: Faculdade de Medicina. Universidade de São Paulo; 2005.

Poikiloderma of Civatte is a dermatosis in which there is hyperpigmentation associated with telangiectasia and atrophy. It occurs predominantly on the neck and face in a symmetric fashion, sparing shade-protected areas under the chin. Many factors are included in its etiology, including genetics, chronic excessive sun exposure, aging, hormonal modifications, and contact hypersensitivity. Currently advocated treatment methods are based on the use of selective photothermolysis via optic radiation, in other words, thermal damage confined to specific targets in the tissue. Clinical studies report promising results with treatment of poikiloderma of Civatte with intense pulsed light, however, they don't describe whether or not the results are accompanied by histopathological alterations. The objective of this study was to assess clinical and histopathological findings in the lesions of poikiloderma of Civatte before and after treatment with intense pulsed light. Sixteen patients with poikiloderma of Civatte in the neck area were treated with five monthly sessions of intense pulsed light, using the $560 \mathrm{~nm}$ cutoff filter. The patients were photographed and biopsies were obtained before the first session and 30 days after the fifth session. Clinical evaluation was performed through comparison of the photographs by five independent observers. Results demonstrated that the vascular component responded better to treatment than the pigmentary component. Histopathological analysis was carried out blindly as to pre- and post-treatment samples, which were unveiled and compared at the end of the readings. After five sessions, in the superficial and deep dermis, there was no difference in the density of elastic fibers nor was there a reduction in vessel number or in medium luminal area of vessels tagged with anti-CD34 antibodies. Quantification of melanin pigment showed a significant reduction within the epidermis, however, this did not occur in the dermis. 


\section{1- INTRODUÇÃO}

\section{1- Definição}

A poiquilodermia é uma lesão dermatológica caracterizada essencialmente por atrofia, pigmentação macular ou reticulada e telangiectasias, sendo encontrada em diferentes condições. É descrita como achado proeminente em algumas síndromes genéticas congênitas, incluindo a síndrome de Rothmund-Thomson, a disqueratose congênita e a síndrome de Mendes da Costa. Dermatoses inflamatórias, como por exemplo o líquen plano, podem levar à alterações poiquilodérmicas. É observada em algumas doenças do tecido conectivo, particularmente na dermatomiosite, sendo também vista no lupus eritematoso e raramente na esclerodermia. Pode ser uma manifestação de alguns linfomas, especialmente a micose fungóide. Nos casos de injúria pelo frio, calor ou radiação ionizante, a poiquilodermia pode ocorrer como um padrão de resposta cutânea (Burton, 1998).

Dentre as poiquilodermias decorrentes de fatores físicos, pode-se incluir a poiquilodermia de Civatte (PC), que tem como papel importante na sua patogênese a exposição cumulativa ao sol. Trata-se de uma afecção que acomete indivíduos de meia idade e idosos, caracterizando-se por pigmentação reticulada marrom-avermelhada com telangiectasias e atrofia, distribuída simetricamente nas regiões laterais da face e pescoço, poupando a área encoberta pelo mento (Bleehen, 1988). 


\section{2- Sinonímia}

Eritrose interfolicular do colo (Leder, 1944), "cutis punctata linearis colli" (Even-Paz, Saguer, 1963), linhas em contas justa-claviculares (Butterworth, Johnson, 1974), linhas estriadas em contas (Calderone, Fenske, 1995), dermatite actínica do pescoço (Raulin et al., 1997b).

\section{3- Aspectos históricos}

O termo poiquilodermia foi utilizado pela primeira vez em 1908 por Jacobi para descrever um quadro clínico caracterizado por manchas avermelhadas, em algumas áreas acastanhadas, com atrofia e prurido intenso, que acometia quase todo o corpo. A análise histopatológica de lesão recente demonstrava infiltrado inflamatório perivascular e perianexial, e a de lesão tardia, atrofia e áreas alternadas de muita e pouca pigmentação. O autor denominou o caso de "poiquilodermia atrofiante vascular". Posteriormente o termo poiquilodermia foi utilizado para descrever doenças diferentes clinicamente, porém com alterações morfológicas semelhantes.

A melanodermatite foi descrita acometendo adultos de ambos os sexos e crianças. Ocorria principalmente no rosto, pescoço e couro cabeludo e consistia de pigmentação acastanhada e descamação leve. $\mathrm{Na}$ histopatologia descreveu a epiderme sem alterações e na derme edema, infiltrado inflamatório denso, células intensamente pigmentadas e 
degeneração do tecido elástico. O autor discutiu a possível etiologia e questionou o papel da luz solar, uma vez que as lesões estavam localizadas principalmente em áreas expostas (Riehl, 1917).

Em 1923 Civatte descreveu três casos de mulheres de meia idade, no período próximo da menopausa, com lesões distribuídas em rede, regional e simétrica, acentuadas na face e pescoço, com evolução indefinida e caracterizadas por eritema, pigmentação e atrofia.

O autor descreveu os achados histopatológicos de duas áreas clinicamente distintas. $\mathrm{Na}$ área eritematosa, pigmentada e infiltrada observou uma epiderme inalterada e na derme infiltrado superficial de linfócitos e fibroblastos, incontinência pigmentar e intensa redução da trama elástica. $\mathrm{Na}$ profundidade, ao redor dos folículos pilo-sebáceos, notou a presença de nódulos linfóides compostos por linfócitos e células mononucleares. Na área atrófica, apontou diminuição de cerca de $1 / 3$ da espessura da pele, especialmente na epiderme e corpo papilar, com desaparecimento das papilas. Entre a derme e a epiderme ressaltou a presença de numerosas massas hialinas agrupadas, com desaparecimento completo da rede elástica. Descreveu ainda, no tecido conectivo, a presença de cavidades preenchidas por células epidérmicas pigmentadas e linfócitos.

O autor relatou cura rápida em 2 casos após o uso de extrato de supra-renal e supôs a condição como decorrendo da deficiência desta glândula, sugerindo o nome de "poiquilodermia supra-renal".

Graham Little (1928) apresentou em 1920, na seção de dermatologia do "Encontro da Real Sociedade de Medicina", dois casos de pacientes com 
pigmentação mosqueada na face, sem eritema ou atrofia, que foram publicados sob o nome de "discromia da face" e que posteriormente identificou como a doença de Civatte. Durante o "Encontro Anual da Associação Britânica de Dermatologia e Sifilografia" em 1927, o autor acrescentou aos casos descritos, mais nove casos da doença de Civatte. Ao comparar com a afecção descrita por Jacobi (1908), defendeu que são entidades distintas. Neste artigo o autor afirmou que Barber foi quem descreveu pela primeira vez um caso sob o nome de doença de Civatte (Barber, 1926 ${ }^{\text {; }}$ apud Graham Little, 1928).

Pierini em 1938 publicou um artigo onde ele agrupou todos os casos descritos na literatura com mais quatro observações pessoais, num total de 47 casos da doença de Civatte. O autor fez uma síntese geral das características dos casos agrupados e descreveu as características da melanose de Riehl, fazendo uma comparação entre os dois quadros. Defendeu que a doença da Civatte é diferente da melanose de Riehl, uma vez que tem localização exclusiva na face e pescoço, cor menos pronunciada, presença de reticulação e telangiectasias, ausência de descamação e foliculose, predileção quase exclusiva pelo sexo feminino, associação com a menopausa e ausência de influência profissional. Sugeriu que não fosse usado o termo poiquilodermia para evitar confusão com o quadro descrito por Jacobi (1908), concordando com o nome de doença de Civatte proposto por Graham Little (1928).

\footnotetext{
${ }^{1}$ Barber Br J Dermatol. 1926:395
} 
Em 1944 Leder fez um estudo em que avaliou sistematicamente 500 pacientes, sendo metade de cada sexo e descreveu um quadro que denominou de eritrose interfolicular do colo. O quadro caracterizava-se fundamentalmente por eritema, telangiectasias e micropápulas foliculares. A área de eleição era a região lateral do pescoço, respeitando a área mediana submentoniana. Era encontrado entre a quarta e a sétima décadas, sendo mais frequente no sexo masculino. Na histopatologia descreveu ectasia das glândulas sebáceas, folículos com pêlo tipo lanugo, dilatação vascular e degeneração das fibras elásticas. O autor afirmou que o quadro era distinto da doença de Civatte pela ausência de atrofia.

Em 1963 Even-Paz e Sagher publicaram sob o nome de "cutis punctata linearis colli" um quadro muito semelhante à PC, caracterizado por numerosas maculo-pápulas arredondadas, pequenas ( $<1 \mathrm{~mm}$ de diâmetro), brancas ou amareladas, agrupadas lembrando linhas salpicadas e onduladas paralelas. Localizavam-se no tórax, região cervical e ombros. Em adultos poderia haver um eritema de base, persistente, que poupava os elementos papulares. O quadro era observado em pacientes que faziam uso de corticóides, após semanas ou meses do início deste, e tendia a aumentar ou diminuir de acordo com a variação da dose desta medicação. $\mathrm{Na}$ histopatologia descreveram hiperplasia das glândulas sebáceas e na coloração para tecido elástico não verificaram anormalidades. Os autores sugeriram que a etiologia estaria relacionada a fatores hormonais, além do possível papel da exposição ao sol ou outros fatores externos. 
Butterworth e Johnson descreveram outro quadro semelhante em 1974, que chamaram de linhas em contas justa-claviculares. Caracterizavase por pequenas pápulas com arranjo que lembrava contas de colar formando discretas linhas paralelas em padrão ondulado na proximidade das clavículas. As pápulas eram cor da pele ou marrom claro, assintomáticas, algumas eram encimadas por um fino pêlo, mediam entre 0,5 a $1,5 \mathrm{~mm}$ de diâmetro, sendo os cordões separados uns dos outros cerca de 3,0 a 4,0 mm. Os autores examinaram 500 pacientes e observaram uma leve predominância no sexo feminino, maior ocorrência em negros, e maior incidência entre 11 e 40 anos de idade, predominando na terceira década. Realizaram biópsias em 10 pacientes e na coloração com hematoxilina e eosina observaram folículos pilossebáceos com glândulas sebáceas alargadas, associadas a pêlo velus, canal folicular dilatado e restos celulares. Colorações especiais para fibras reticulares e elásticas, matriz extra-celular e padrão vascular, além de estudos enzimáticos para avaliação do metabolismo foram normais.

Jacoby sugeriu que as linhas em contas justa-claviculares e a "cutis punctata linearis colli" seriam a mesma entidade, sendo provavelmente uma variante anatômica comum em negros ou podendo ser induzida por terapia prolongada com corticóides. Butterworth e Johnson responderam afirmando não saber se seriam a mesma condição ou não. Afirmaram que as primeiras ocorreram em um grupo etário mais jovem, a maioria dos pacientes nunca recebera corticóides, além de haver diferenças na cor e distribuição das lesões (Jacoby, 1976). 
Duarte (1996) atribuiu as controvérsias das primeiras publicações sobre a PC ao desconhecimento das publicações históricas, considerando que foram descritos casos semelhantes sob nomes diferentes. Afirmou que o quadro descrito como linhas estriadas em contas se sobreporia ao descrito por Civatte em 1923.

Alguns dos quadros descritos acima (Leder, 1944; Even-Paz, Sagher, 1963; Butterworth, Johnson, 1974) apresentam várias características comuns, levando a supor que realmente se tratam da mesma entidade. De forma semelhante, constata-se que atualmente, ainda em alguns trabalhos, ocorre o emprego de nomes diferentes da PC, como por exemplo eritrose interfolicular do colo de Leder (Raulin et al., 1997a; Raulin et al., 1997b; Schroeter, Neumann, 1998)

\section{4- Classificações}

Em 1984, em artigo sobre as alterações decorrentes da exposição crônica ao sol, a PC foi classificada na classe das afecções benignas, as quais ocorreriam com maior frequência em indivíduos com idade avançada, com alta dose cumulativa de radiação solar e pele clara (Goldberg, Altman, 1984).

$\mathrm{Na}$ classificação das fotodermatoses proposta por Azulay et al. em 1989, os autores as dividiram em cinco grupos: 1- Tóxicas primárias; 2Induzidas por substâncias químicas; 3- Idiopáticas; 4- Miscelânea; 5Precipitadas ou agravadas pelas radiações solares. A PC estaria classificada 
dentro do grupo miscelânea, que incluiria entidades nitidamente produzidas pelas radiações solares, mas com mecanismo não conhecido e que não se enquadrariam nos outros grupos.

Em 1995, uma extensa revisão sobre elastose actínica foi realizada por Calderone e Fenske, os quais fizeram citações individuais sobre as várias afecções, porém omitiram a PC. Citaram as linhas estriadas em contas e compararam com a "cutis punctata linearis colli" e as linhas em contas justa-claviculares, distinguindo a primeira das outras por ser causada primariamente por exposição crônica à radiação ultravioleta.

Uma publicação sobre as formas adquiridas de pigmentação do pescoço colocou entre as pigmentações induzidas pelo sol, a dermatite berloque, a melanose de Riehl, a poiquilodermia de Civatte e outras. A melanose de Riehl foi apontada como um importante diagnóstico diferencial da poiquilodermia de Civatte (Lautenschlager, Itin, 1998). Inicialmente alguns autores consideraram que fossem a mesma entidade, porém atualmente sabe-se que são distintas. A melanose de Riehl trata-se de uma dermatite pigmentada marron-acinzentada, que se desenvolve na face, mais intensa na fronte e têmporas. Os autores acreditam que pode estar associada com sensibilidade de contato ou fotocontato a cosméticos (Serrano et al., 1989). Autores japoneses propuseram o nome de dermatite pigmentada por cosméticos (Nakayama et al., 1976). 


\section{5- Etiologia}

Graham (1989) afirmou que a PC é vista mais comumente em mulheres de meia-idade e trabalhadores de ambientes abertos, particularmente aqueles com pele clara. Defendeu que a etiologia estaria relacionada à exposição crônica ao sol, associada ao envelhecimento normal da pele. Não acredita no papel dos cosméticos, argumentando que muitos pacientes acometidos nunca os utilizaram. $O$ autor afirmou que estaria havendo confusão com a dermatite berloque.

A dermatite berloque ocorre após a aplicação na pele de cosméticos que contenham óleo de bergamota e a exposição subsequente à luz solar, devido a uma reação fototóxica induzida pela radiação UVA sobre o 5metoxipsoraleno ou bergapteno, o componente ativo do óleo de bergamota. A reação resulta em hiperpigmentação da pele, com ou sem eritema precedendo. O aspecto clássico é em forma de gota, usualmente nas laterais do pescoço, em mulheres adultas. Zaynoun et al. (1981) sugeriram uma possível relação entre a hiperpigmentação da poiquilodermia de Civatte e o uso de perfumes que contenham bergapteno. Isto foi aventado após a observação, em estudo não controlado, de eritema e subsequente hiperpigmentação quando se realiza fototeste de contato com esta substância nos pacientes portadores de PC.

As informações a respeito do uso de cosméticos na gênese da PC são controversas. No estudo de Duarte (1996) que envolveu 79 pacientes portadores de PC, a avaliação quanto ao uso de cosméticos revelou 
associação positiva em $100 \%$ dos homens, os quais usavam sabonete ou creme para barbear, e em $70 \%$ das mulheres, as quais usavam perfumes, porém o autor ressaltou que estas informações deveriam ser vistas com cuidado por serem relatos subjetivos dos pacientes. Considerando as descrições históricas, o autor acredita que as lesões causadas por contactantes na face e pescoço têm uma expressão clínica diferente das lesões descritas por Civatte em 1923, e concluiu que a PC não tem relação com o uso de cosméticos.

Em 2001 Sahoo e Kumar relataram o caso de uma paciente com poiquilodermia de Civatte e teste de contato positivo para Kathon ${ }^{\circledR} \mathrm{CG}$, um preservante usado em cosméticos. Após tomar medidas de fotoproteção e evitar contato com o produto, a paciente apresentou melhora das lesões. Concluíram que o alérgeno teve papel importante no desencadeamento e na manutenção da poiquilodermia de Civatte.

Outro estudo realizado, para tentar esclarecer o papel da hipersensibilidade de contato, foi o de Katoulis et al. em 2002. Foram envolvidos 32 pacientes com PC e 97 controles, os quais foram submetidos a teste de contato, fototeste de contato e fototeste para medição da dose eritematosa mímina (DEM). Os resultados mostraram significância estatística de $5 \%$ na freqüência de reações positivas no teste de contato a fragrâncias no grupo com PC em relação ao grupo-controle. Além disto, no grupo com PC observou-se alta incidência de reações positivas aos alérgenos da bateria padrão. Os fototestes de contato foram negativos a fragrâncias e outros alérgenos, e no fototeste a DEM do grupo com PC estava dentro dos 
limites normais nos comprimentos de onda avaliados. Os autores sugeriram que a hipersensibilidade de contato pode ser a base da PC. Argumentaram que os resultados falam contra o mecanismo de fotocontato, entretanto não o exclui, uma vez que foram testados os fotoalérgenos mais comuns, podendo outros terem ficado de fora. Além disto, relataram que quatro das oito pacientes com teste de contato positivo à fragrâncias mostraram melhora clínica significativa após a suspensão total do uso de perfumes. Sugeriram então que o teste de contato com a bateria padrão seja feito como procedimento diagnóstico de rotina nos pacientes com poiquilodermia de Civatte e que o afastamento dos alérgenos revelados pode ser de valor no manejo destes pacientes.

Ainda em relação à etiologia, Duarte em 1996 afirmou que o fator genético tem importância vital, considerando-se a maior incidência nos pacientes com fototipos II e III da classificação de Fitzpatrick (1988).

Em 1999 Katoulis et al. publicaram um trabalho decisivo que comprovou a influência genética na ocorrência da PC. Descreveram duas famílias não relacionadas e sem história de consangüinidade, em que observaram a ocorrência da PC em vários membros de sexos diferentes e em gerações sucessivas. Os pacientes não possuíam influências ambientais, hormonais ou de fotosensibilização comuns. O padrão de ocorrência sugeriu herança autossômica dominante com penetrância variável. Os autores acreditam haver predisposição geneticamente determinada para a doença, possivelmente expressa como susceptibilidade aumentada da pele a doses normais de radiação ultravioleta. Os fatores 
contribuintes apontados seriam os mecanismos fotoalérgicos, o desequilíbrio hormonal associado à menopausa e o processo normal de envelhecimento.

Em resumo, as evidências etiopatogênicas apontam para alguns fatores:

1- Exposição cumulativa ao sol: pela distribuição das lesões em áreas expostas poupando as regiões anatomicamente cobertas;

2- Fatores hormonais: pela distribuição quanto ao sexo e idade, além de maior ocorrência após a menopausa, inclusive nos casos de menopausa iatrogênica;

3- Envelhecimento normal: pela ocorrência em idades mais avançadas;

4- Fatores genéticos: pelo relato de casos familiares onde outros fatores causais estavam ausentes;

5- Hipersensibilidade de contato com ou sem fotossensibilização: pela descrição de testes positivos a perfumes e cosméticos, que poderiam atuar como desencadeadores ou exacerbadores.

(Duarte, 1996; Bleehen, 1998; Katoulis et al., 1999; Sahoo, Kumar, 2001; Katoulis et al., 2002)

\section{6- Patogenia}

Foi sugerida uma história natural para o desenvolvimento das alterações observadas na PC. Alterações do tecido elástico e colágeno seriam provavelmente causadas pela radiação UV. Nas mulheres, haveria alteração da taxa de produção de colágeno decorrente da diminuição dos níveis de estrogênio na menopausa. O envelhecimento cronológico também 
contribuiria com as alterações atróficas. Dessa forma, o tecido conectivo dérmico alterado levaria à ocorrência de telangiectasias por perda do suporte vascular. O uso de perfumes e cosméticos ocasionaria um quadro de hipersensibilidade de contato tardia, levando a alterações da membrana basal que resultaria em incontinência pigmentar e clinicamente em hiperpigmentação reticulada. A predisposição genética aumentaria as influências intrínsecas e extrínsecas (Katoulis et al., 2002).

\section{7- Histopatologia}

As poiquilodermias caracterizam-se histologicamente pela presença de degeneração vacuolar focal das células basais, epiderme com espessura variando de hiperplasia leve a atrofia, telangiectasias e perda das fibras elásticas superficiais (Mehregan et al., 1995).

Duarte em 1996 analisou 79 biópsias de pacientes com PC, notando na epiderme hiperceratose discreta e compacta em alguns casos, retificação e atrofia supra-papilar, áreas focais de hiperpigmentação e degeneração hidrópica focal nos queratinócitos basais. Na derme observou degeneração basofílica do tecido conjuntivo, derrame pigmentar, proliferação vascular com vasos de paredes delgadas, tortuosos e dilatados, com infiltrado inflamatório linfo-histiocitário discreto ao redor, assim como dos folículos pilo-sebáceos. Notou a presença de hiperplasia de glândulas sebáceas nas lesões mais exuberantes. As colorações para fibras elásticas (Verlhof e 
resorcina-fucsina) demonstraram que estas estavam agrupadas de modo grosseiro formando grumos, fragmentadas e aumentadas em número.

Em 1997 Bertino realizou um estudo comparativo quantitativo das fibras elásticas propriamente ditas na PC em relação a um grupo controle, observando através da coloração para fibras elásticas (Gomori-CameronSteele) que as fibras elásticas propriamente ditas foram encontradas agrupadas de modo grosseiro, fragmentadas e em maior número, no grupo com PC em relação ao grupo controle, e as fibras oxitalânicas estavam ausentes no grupo com PC.

Em outro estudo biópsias de nove pacientes com PC apresentaram na microscopia óptica alterações leves das células basais epidérmicas, vacúolos na junção dermo-epidérmica, degeneração focal das fibras colágenas na derme papilar e macrófagos contendo grânulos compatíveis com melanina, dispersos na derme. Os achados ultraestruturais mais importantes foram as alterações do tecido conectivo dérmico e a incontinência pigmentar. A camada basal e a membrana basal apresentaram alterações pouco significativas, o que levou o autor a afirmar que diferenciaria a PC da melanose de Riehl (Katoulis et al., 2001).

\section{8- Importância clínica}

A importância clínica reside na sua alta prevalência e no desfiguramento estético que provoca (Katoulis et al., 2002). Além da 
implicação na aparência do paciente, há relatos ocasionais de queimação, prurido e desconforto (Graham, 1989).

Segundo Goldman e Bauman (1984), a poiquilodermia é uma marca de exposição crônica ao sol que indica a necessidade de fotoproteção e observação contínua para a prevenção de queratoses actínicas e neoplasias malignas. Os autores defendem que o tratamento é importante não apenas pela questão estética, mas possivelmente por atuar na prevenção de queratoses.

O estudo de Duarte (1996) incluiu 854 pacientes, os quais foram triados para verificar a presença de cardiopatia isquêmica associada à PC. Foram submetidos à biópsia todos os pacientes com PC $(n=79)$, alguns pacientes que tinham somente cardiopatia $(n=18)$ e alguns pacientes sem nenhum dos quadros $(n=6)$. Houve associação positiva entre a presença de cardiopatia isquêmica e de fibras elásticas espessadas e agrupadas de modo grosseiro ao redor dos vasos da derme. A PC ocorreu com maior freqüência nos pacientes portadores de cardiopatia (infarto do miocárdio e angina), sendo a associação de significância estatística. O autor afirma que a PC pode não ter uma implicação apenas estética, uma vez que pode ser vista como uma manifestação clínica de um distúrbio das fibras elásticas, desencadeada pela radiação solar, indicando uma possível elastólise sistêmica. A presença da PC poderia indicar uma predisposição individual a distúrbios cardiovasculares. 


\section{9- Tratamento}

Na PC recomenda-se o uso de filtro solar com alto fator de proteção e evitar o uso de esteróides tópicos, considerando-se o dano ao tecido elástico (Graham, 1989).

Várias tentativas de tratamento não foram bem sucedidas por se mostrarem ineficazes e/ou com efeitos colaterais indesejados, e incluíram o uso de clareadores como a hidroquinona, eletrocirurgia, "peelings" químicos, LASER de argônio e crioterapia (Geronemus, 1990; Goldman, Weiss, 2001). Atualmente os tratamentos adotados baseiam-se na utilização de outros tipos de LASER e da luz intensa pulsada (LIP), atuando ambos através do princípio da fototermólise seletiva, que busca a absorção pelos cromóforos melanina e oxihemoglobina.

Os cromóforos são átomos ou moléculas do tecido irradiado que absorvem os fótons emitidos pela fonte de luz. Possuem bandas características de absorção em cada comprimento de onda. Assim, de acordo com o comprimento de onda emitido, sabe-se quais são os cromóforos-alvo que serão atingidos (Anderson, 1994) (Figura1). 


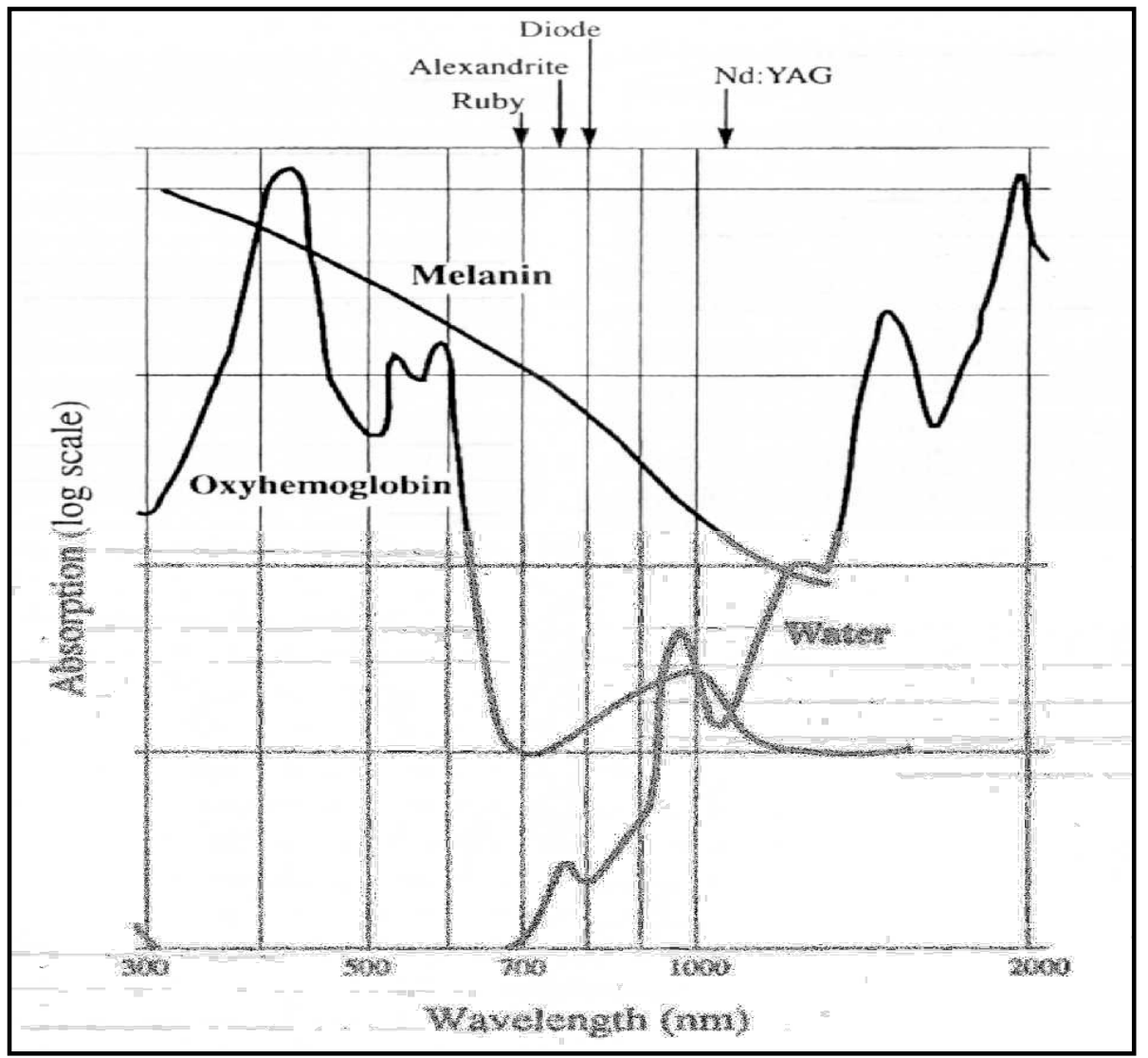

FONTE:: Weiss RA, Dover JS. Laser surgery of leg veins. Dermatol Clin, 2002; 20:19-36

Figura 1. Curvas de absorção dos cromóforos oxihemoglobina, melanina e água de acordo com a variação do comprimento de onda

O princípio da fototermólise seletiva foi descrito em 1983, por Anderson e Parrish. Baseia-se no conceito de que se uma quantidade suficiente de energia com comprimento de onda e duração de pulso adequados é aplicada a um alvo, pode-se obter destruição deste com dano limitado ao tecido normal adjacente. O objetivo é confinar o dano térmico aos alvos escolhidos no nível ultraestrutural, celular ou tecidual, sendo as áreas adjacentes poupadas, reduzindo a destruição disseminada e a fibrose inespecífica. Um pré-requisito é que os alvos tenham maior absorção óptica do comprimento de onda do que os tecidos vizinhos. 
Durante a exposição à luz, a energia radiante é convertida em calor em cada alvo da área irradiada. O calor é inicialmente confinado ao alvo, sendo que imediatamente após a exposição, o alvo resfria por difusão térmica e aquece os tecidos adjacentes. Ao final da exposição, a temperatura do alvo ultrapassou a requerida para a desnaturação térmica, enquanto que os tecidos adjacentes ficaram bem abaixo desta temperatura (Anderson, Parrish, 1983).

$\mathrm{Na}$ fototermólise seletiva, vários mecanismos são propostos para explicar como o dano térmico promove a sua ação, entre eles a desnaturação térmica, o dano mecânico por expansão térmica rápida (cavitação) e mudanças na estrutura química primária (pirólise) (Anderson, 1994).

\subsection{1 - Tratamento da poiquilodermia de Civatte com LASER}

O LASER de corante pulsado de $585 \mathrm{~nm}$ tem sido usado com bons resultados no tratamento da PC. A luz amarela é bastante específica no tratamento das lesões vasculares pois sua emissão é próxima do pico de absorção $\beta$ da oxihemoglobina. Apontam-se como vantagens da sua utilização, além do bom resultado estético com poucos efeitos adversos, a não necessidade de agentes anestésicos, o reduzido número de sessões e a possibilidade de tratamento rápido de grandes áreas em um curto período de tempo. A grande desvantagem do tratamento é a ocorrência de púrpura azul escura a preta que se desenvolve 5 a 10 minutos após a aplicação e persiste 
por no mínimo 7 a 10 dias, sendo depois substituída por uma coloração marrom-amarelada que geralmente desaparece em mais 7 dias. Não há necessidade de outros cuidados além da fotoproteção, porém chama bastante a atenção (Wheeland, Applebaum, 1990).

Vários estudos relatam os resultados do tratamento de pacientes com PC com esse aparelho. Enquanto mostram bons resultados na resolução do componente vascular, também alertam para o risco de hipopigmentação e cicatriz, observada em alguns casos meses após o tratamento, mesmo após a realização de teste prévio em que estes não ocorreram (Geronemus, 1990; Wheeland, Applebaum, 1990; Clark, Jimenez-Acosta, 1994; Geronemus et al., 1999; Haywood, Monk, 1999; McCoy, Grevelink, 1998). Alguns autores contra-indicam o tratamento se houver predomínio do componente pigmentar (Haywood, Monk, 1999).

$\mathrm{Na}$ literatura encontra-se ainda o relato de caso de um paciente com PC que foi submetido a tratamento com LASER KTP (potássio titanil fosfato) de $532 \mathrm{~nm}$. Os autores referem resultado muito bom com redução das telangiectasias e hiperpigmentação após quatro sessões. Houve desenvolvimento de hiperpigmentação pós-inflamatória, que na avaliação após 6 meses havia regredido parcialmente. Os autores comentaram que a luz verde de 532 nm está próxima de um dos picos de absorção da oxihemoglobina, sendo também fortemente absorvida pela melanina, desta forma, efetiva para o tratamento dos componentes telangiectásico e pigmentar da PC. (Batta et al., 1999). 


\subsection{2 - Luz intensa pulsada}

O sistema de luz intensa pulsada difere do LASER por ser uma luz policromática, não-coerente, isto é, emitida em todas as direções, e nãocolimada, ou seja, não paralela. Seu espectro extende-se de 500 a 1200 $\mathrm{nm}$. Este sistema possibilita a escolha de diferentes filtros, os quais atuam bloqueando a emissão dos comprimentos de onda mais curtos do que o filtro utilizado. Por exemplo, quando se utiliza o filtro de $640 \mathrm{~nm}$, só ocorre emissão no espectro de 640 a 1200 nm (Schroeter, Neumann, 1998).

A profundidade de penetração aumenta quanto mais longos forem os comprimentos de onda utilizados. Desta forma, a escolha do filtro será feita selecionando-se o espectro desejado que corresponda à profundidade da estrutura que se deseja atingir.

A escolha do filtro também deve se adaptar ao fototipo do paciente, sendo que nos fototipos escuros, em que há maior concentração de melanina, utilizam-se filtros que selecionam os comprimentos de onda mais longos, para reduzir a absorção por esta (menor sobreposição ao seu coeficiente de absorção) e assim prevenir efeitos colaterais intensos (Fitzpatrick, 1988; Raulin et al., 2003) (Figura 1).

Este sistema também permite a escolha pelo operador de parâmetros como a duração e o fracionamento dos pulsos, além da duração do intervalo entre os pulsos. A duração do pulso deve ser menor do que o tempo de relaxamento térmico (TRT) do tecido-alvo, pois em exposições muito longas ocorre aquecimento uniforme dos tecidos adjacentes e consequente necrose 
de coagulação não-específica (Anderson, Parrish, 1983). O TRT corresponde ao tempo que o tecido leva para perder $50 \%$ do calor sem conduzi-lo às estruturas adjacentes.

O fracionamento dos pulsos em duplos ou triplos permite que a epiderme e os vasos menores resfriem nos intervalos entre os pulsos, enquanto os vasos mais grossos e folículos pilosos permanecem quentes pelo aquecimento aditivo. Desta forma, ocorre diminuição do risco de dano térmico à pele, pois não atinge a temperatura que causaria este (Raulin et al., 1999; Arias, Ferrando, 2001). Isto ocontece pois objetos de tamanhos e formas diferentes possuem TRTs diferentes (Anderson, 1994; Schroeter, Neumann, 1998).

Outro parâmetro que o operador pode regular é a fluência, que é a quantidade de energia emitida por unidade de área, usualmente medida em joules por centímetro quadrado $\left(\mathrm{J} / \mathrm{cm}^{2}\right)$ (Anderson, 1994). A fluência diminui rápido com a profundidade. Desta forma, a maior parte da energia é dissipada nas camadas superiores da pele, principalmente na epiderme (Weiss et al., 2000).

Para proteger a epiderme de queimadura, a pele deve estar suficientemente resfriada durante o tratamento. Isto pode ser conseguido através da utilização de gel resfriado, bolsa de gelo, spray de criógeno ou ponteiras resfriadas (Raulin et al., 2003). Além de possibilitar a transferência do calor da pele para este, a utilização do gel tem a função de otimizar o acoplamento da luz à pele (Negishi et al., 2002). 
Entre os efeitos colaterais descritos com a utilização deste sistema, estão a sensação de queimação ou punctura durante a aplicação, eritema transitório, edema ocasional, púrpura transitória, crostas, hiper e hipopigmentação. Estes são mais comuns nos fototipos escuros, nos pacientes com a pele bronzeada e no tratamento da hipertricose (Raulin et al., 2003).

O primeiro aparelho comercializado com a tecnologia da LIP foi disponibilizado em 1994. Atualmente as indicações de uso são inúmeras, incluem hemangiomas planos, hemangiomas cavernosos benignos, malformações venosas benignas, telangiectasias essenciais, telangiectasias dos membros inferiores, poiquilodermia de Civatte, efélides, lentigos solares, nevos melanocíticos, hipertricose, rítides faciais e estrias (Hernández-Pérez et al., 2002a; Raulin et al., 2003).

\subsection{3 - Tratamento da poiquilodermia de Civatte com luz intensa pulsada}

O tratamento da poiquilodermia de Civatte requer comprimentos de onda que sejam absorvidos por dois cromóforos, a oxihemoglobina e a melanina. Os vasos ectásicos localizam-se na derme papilar e contém principalmente oxihemoglobina, que absorve luz a 418, 542 e $577 \mathrm{~nm}$. A melanina, concentrada na camada basal da epiderme, absorve luz continuamente em uma faixa de 250 a 1200 nm, sendo a absorção maior com os comprimentos de onda mais curtos. Com a LIP os alvos são os 
vasos e a melanina dérmica e epidérmica, pela ampla faixa de comprimentos de onda (Weiss et al., 2000) (Figura 1).

Em 1997 publicaram-se os primeiros relatos de tratamento da PC com luz intensa pulsada, que o autor se refere como eritrose interfolicular do colo. Usou-se o aparelho PhotoDerm ${ }^{\circledR}$ VL com filtro de $550 \mathrm{~nm}$ em um paciente com poiquilodermia de Civatte na região cervical, com clareamento completo após 10 sessões. Os efeitos colaterais observados foram eritema leve, edema, hipopigmentação transitória (nos pacientes muito bronzeados) e hiperpigmentação transitória (Raulin et al., 1997b). No mesmo ano, em um artigo de revisão sobre as possibilidades de tratamento com a LIP, o autor cita a PC (Raulin et al., 1997a).

Schroeter e Neumann (1998) trataram 15 pacientes com eritrose interfolicular do colo com o aparelho PhotoDerm ${ }^{\circledR}$ VL com filtros de 515 e/ou $550 \mathrm{~nm}$, observando clareamento de $90 \%$ do componente vascular após 1 sessão. Observaram raros efeitos colaterais, em alguns casos houve hipopigmentação que se resolveu em poucas semanas. Apontam o aparelho como uma nova alternativa de tratamento para esta afecção.

Em 2000 Weiss et al. publicaram uma revisão de 5 anos de tratamento da PC na região cervical e tórax com LIP, que reuniu uma casuística de 135 pacientes (97 mulheres e 38 homens). Utilizaram-se filtros de 515, 550 e $570 \mathrm{~nm}$ e após uma média de três sessões (1 a 5) com intervalo mensal, observou-se melhora de 75 - 100\%, em 111 de 135 pacientes $(82 \%)$. Os resultados foram obtidos pela comparação das fotografias, que foram julgadas pelos autores e pelos pacientes. Um achado 
adicional que não fazia parte da avaliação foi a melhora subjetiva da textura cutânea com melhora das rugas, observada por $70 \%$ das mulheres. Os efeitos colaterais observados foram eritema com resolução em 24 a 72 horas, púrpura com resolução em 3 a 5 dias, crostas, áreas lineares não tratadas e hipopigmentação. A hipopigmentação ocorreu em 4 pacientes, havendo resolução em 1 a 2 anos em dois deles. Os autores concluíram que a LIP é efetiva no tratamento dos componentes telangiectásico e hiperpigmentar da poiquilodermia de Civatte.

Em 2001 foi publicado um estudo idêntico pelos mesmos autores. Pela semelhança das informações, tem-se a impressão de que se tratam dos mesmos casos, porém com casuística menor (66 pacientes) e resultados inferiores, isto é, melhora de 75 a $100 \%$ do quadro em $42 \%$ dos pacientes após uma média de 2,8 tratamentos. A melhora subjetiva da textura cutânea e das rugas finas e os efeitos colaterais descritos foram idênticos ao estudo publicado em 2000 (Goldman, Weiss, 2001).

1.9.4- Modificações histopatológicas após a utilização da luz intensa pulsada

Os trabalhos citados descrevem resultados clínicos muito interessantes, porém ainda faltam informações sobre o que acontece a nível tecidual que corresponda ao que se observa a olho nu no tratamento da poiquilodermia de Civatte com a luz intensa pulsada. $\mathrm{Na}$ literatura encontram-se alguns trabalhos referentes às alterações histopatológicas após o uso da LIP para o tratamento do fotoenvelhecimento. 
Em 2000 Bitter realizou biópsia na fronte de um paciente, antes do tratamento e 4 semanas após a última sessão com o aparelho de LIP Vasculight ${ }^{\circledR}$. Foram realizadas entre 4 a 6 sessões com filtros de 550 e/ou 570 nm (não especificado). A avaliação histológica mostrou novo colágeno na derme papilar e em toda a espessura da derme reticular, além de resolução do infiltrado inflamatório dérmico superficial e dos melanófagos da derme papilar.

Em outro estudo, cinco mulheres de origem hispânica com fotoenvelhecimento facial foram tratadas com o aparelho VascuLight ${ }^{\circledR}$ Plus. Utilizou-se principalmente o filtro de $645 \mathrm{~nm}$ e realizaram-se cinco sessões com intervalo de 2 semanas entre cada uma. Foram feitas biópsias na região malar esquerda antes da $1^{\text {a }}$ sessão e 1 semana após a $5^{\mathfrak{a}}$ sessão. Os cortes foram corados com hematoxilina e eosina e avaliados por dois dermatopatologistas de forma cega. Os parâmetros avaliados na epiderme foram atrofia, rolhas córneas, perda de polaridade, liquefação da camada basal e medida da espessura epidérmica. Na derme incluíram elastose, edema, telangiectasias e inflamação. A avaliação histológica pós-tratamento mostrou que houve melhora de todos os parâmetros epidérmicos. Houve aumento da espessura epidérmica com significância estatística. Os parâmetros dérmicos também mostraram graus variados de melhora. Em três pacientes observou-se diminuição de 60 a $70 \%$ da massa elastótica. A elastose foi substituída por um novo colágeno mais ordenado com aspecto fibrilar, principalmente na derme superficial e reticular superior (HernándezPérez, Ibiett, 2002b). 
No mesmo ano publicou-se um estudo com resultados divergentes, isto é, não houve síntese de colágeno. Foram tratadas cinco mulheres, fototipos I a IV, portadoras de dano solar leve na face, com cinco sessões mensais de LIP com o aparelho Quantum ${ }^{\circledR}$ SR. Utilizou-se o filtro de 560 nm. Realizaram-se biópsias nas áreas tratadas e não tratadas 1 semana, 3 meses e 6 meses após a primeira sessão. Os cortes foram corados com hematoxilina e eosina, tricrômio de Masson, von Gieson e coloração para reticulina. Em 3 pacientes foram realizadas biópsias adicionais prétratamento, após 1 semana e após 6 meses para microscopia eletrônica. Não se observou diferença evidente na quantidade e qualidade das fibras colágenas, elásticas e de reticulina antes e após o tratamento. A análise ultraestrutural também não mostrou alterações morfológicas significativas nas fibras elásticas ou colágenas. Em dois de três casos, observaram-se as fibras colágenas da derme papilar arranjadas em padrão discretamente mais compacto do que nas áreas não tratadas. Não houve alterações nas estruturas epiteliais, incluindo a zona da membrana basal. Ocorreu necrose de coagulação dos Demodex folliculorum presentes nos folículos pilosos. Os autores acreditam que a diminuição do número destes microorganismos se correlacionaria com uma redução da inflamação perifolicular, o que provavelmente contribuiu com a melhora estética observada (Prieto et al., 2002). 


\section{2- OBJETIVOS}

Considerando-se os trabalhos descritos que relatam bons resultados clínicos no tratamento da poiquilodermia de Civatte com a luz intensa pulsada, e a inexistência de informações sobre os achados histopatológicos, antes e após esse procedimento; efetuou-se a aplicação de LIP em 16 pacientes portadores desta afecção utilizando-se o filtro de $560 \mathrm{~nm}$, sendo realizadas cinco sessões mensais e os pacientes avaliados antes e após o tratamento. Objetivou-se avaliar:

1- resposta clínica

2- efeitos adversos do tratamento

3- alterações histopatológicas em relação à densidade das fibras elásticas, quantidade de pigmento melânico, número e área do lúmen dos vasos. 


\section{3- CASUÍSTICA E MÉTODO}

\section{1- Casuística}

Foram incluídos 16 pacientes provenientes do ambulatório de dermatoses inestéticas do Departamento de Dermatologia do Hospital das Clínicas da Faculdade de Medicina da Universidade de São Paulo (HCFMUSP) e do ambulatório de Dermatologia da Faculdade de Medicina da Universidade de Santo Amaro (UNISA).

Quinze pacientes eram do sexo feminino e um era do sexo masculino.

As idades variaram entre 43 e 56 anos (média de 47 anos).

Possuíam fototipos II e III da classificação de Fitzpatrick (1988).

Foi obtida aprovação da Comissão de Ética para Análise de Projetos de Pesquisa (CaPPesq) em 24 de abril de 2003.

Os procedimentos tiveram início após a explicação detalhada da pesquisa e a assinatura do termo de consentimento livre e esclarecido, segundo a Resolução do Conselho Nacional de Saúde 196, de 10 de outubro de 1996. (Anexo A) 


\section{2- Critérios de inclusão, exclusão e suspensão do paciente da pesquisa}

O critério de inclusão foi a presença da poiquilodermia de Civatte na região cervical.

Foram excluídos:

a) todos os pacientes que haviam sido previamente submetidos a algum procedimento cosmético na região cervical, incluindo tratamento com LASER ou LIP;

b) pacientes com doenças cutâneas em atividade na região cervical;

c) gestantes;

d) portadores de doenças agravadas pela luz;

e) pacientes em uso de drogas fotossensibilizantes;

f) pacientes com história de quelóide ou cicatriz hipertrófica;

g) pacientes com a pele bronzeada e/ou com fototipos $\mathrm{V}$ e $\mathrm{VI}$ de Fitzpatrick (1988).

A suspensão do paciente da pesquisa ocorreria a qualquer momento por desejo do paciente ou a critério do pesquisador diante de situações que demonstrassem prejuízo ao paciente.

\section{3- Coleta do material fotográfico e biópsias}

Após a inclusão do paciente, este era submetido à entrevista (Anexo B), a registro fotográfico e à biópsia da região cervical. 
Todas as fotografias foram feitas pela mesma pessoa, sendo que para cada paciente em três posições: cervical anterior, lateral direita e lateral esquerda. Utilizou-se uma câmera fotográfica digital para a realização das fotografias (Cyber-shot DSC-F707®, Sony Corporation, Tokyo - Japan). As imagens foram capturadas com uma resolução de 5.0 mega pixels.

Foi realizada biópsia de pele da região cervical direita em área acometida pela PC, utilizando "punch" descartável $n^{\circ} 4$ após anestesia infiltrativa com lidocaína $2 \%$ com vasoconstrictor. A sutura foi feita com fio mononylon 5.0 e os pontos retirados após 1 semana. Os fragmentos de pele foram imersos em formol $10 \%$ e encaminhados ao Setor de Dermatopatologia do Serviço de Dermatologia do HC-FMUSP.

Após 30 dias da quinta sessão foi realizado novo controle fotográfico e nova biópsia em área adjacente à da primeira biópsia.

\section{4- Tratamento}

Os pacientes foram submetidos à 5 sessões mensais na região cervical com o aparelho de luz intensa pulsada (IPL Quantum SR/HR ${ }^{\circledR}$, ESC Medical Systems Ltd., Israel) (Figura 2A-B). Este aparelho emite luz no espectro de 560 a $1200 \mathrm{~nm}$, tendo quatro opções de filtro para serem utilizados: 560, 640, 695 e $755 \mathrm{~nm}$. Neste estudo foi escolhido o filtro de 560 nm, o qual permite a emissão dos comprimentos de onda mais curtos, que têm penetração mais superficial, buscando-se atingir os alvos desejados. A escolha se baseou nos trabalhos anteriores de tratamento da PC com LIP, 
os quais também utilizaram filtros próximos desta faixa obtendo bons resultados clínicos (Raulin et al., 1997b; Schroeter, Neumann, 1998; Weiss et al., 2000; Goldman, Weiss, 2001). Somente após o início do protocolo, publicou-se o estudo de Prieto et al. (2002), que demonstrou resultados histológicos pobres no tratamento do fotoenvelhecimento com LIP utilizando o filtro de $560 \mathrm{~nm}$.

A

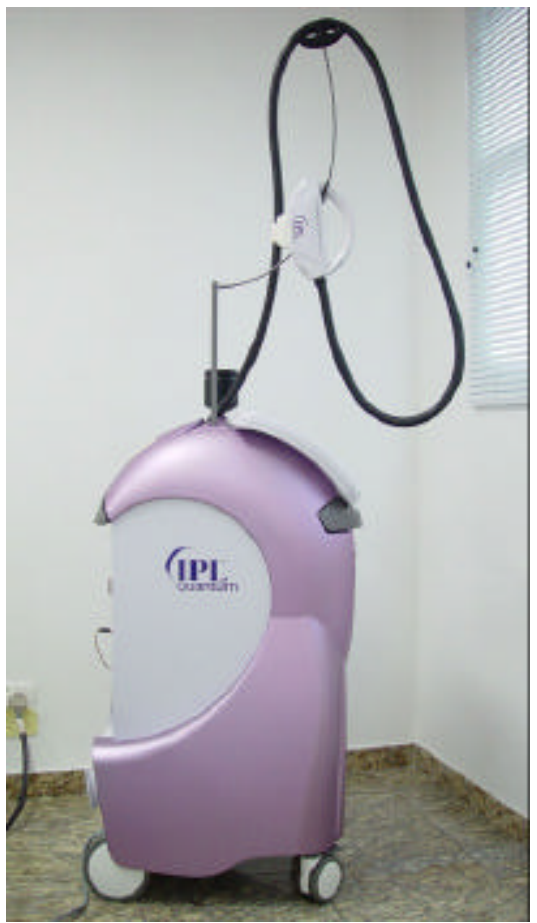

B

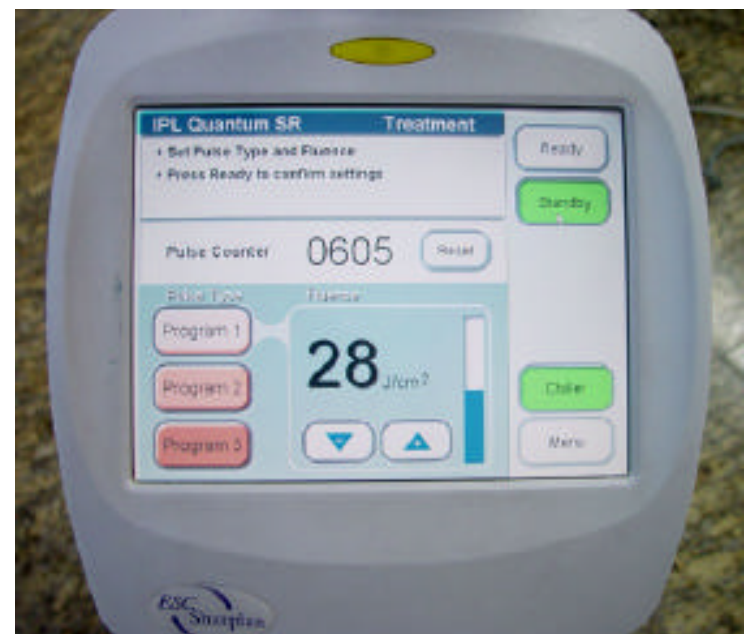

Figura 2. A: Aparelho IPL Quantum SR/HR®. B: Monitor do aparelho

O aparelho possibilita o uso de fluências entre 15 e $45 \mathrm{~J} / \mathrm{cm}^{2}$ e duração de pulso entre 2 e $10 \mathrm{~ms}$. Os pulsos podem ser duplos ou triplos e o intervalo entre os pulsos pode variar entre 5 e $60 \mathrm{~ms}$. O tamanho da ponteira, isto é, a extremidade por onde ocorre a emissão da luz é de 8 x 34 
mm. Neste estudo foram utilizadas as seqüências de parâmetros préajustados 1 ou 2 sugeridos pelo fabricante, de acordo com os fototipos II ou III dos pacientes, respectivamente. O programa 1 consiste de 2 pulsos, sendo a duração do primeiro de 2,4 ms e do segundo de $4 \mathrm{~ms}$, com intervalo de 15 ms entre cada pulso. O programa 2 é idêntico, exceto a duração do segundo pulso que é de $5 \mathrm{~ms}$. As fluências variaram de 25 a $33 \mathrm{~J} / \mathrm{cm}^{2}$, sendo que se iniciavam com valores menores e de acordo com a resposta observada eram modificados, isto é, mantidos se havia clareamento satisfatório ou aumentados se insatisfatório. A tolerância do paciente ao desconforto também era fator que influenciava a modificação ou não da fluência. No caso de ocorrência de púrpura ou ruptura da integridade epidérmica a fluência era diminuída ou mantida com a ponteira sendo levemente afastada da pele. O sistema de resfriamento do aparelho foi utilizado no modo "máximo".

Foi utilizado gel resfriado transparente formando uma camada de 3 a $5 \mathrm{~mm}$ de espessura, para o acoplamento entre a ponteira e a pele do paciente e também com a finalidade de proteger a epiderme, uma vez que possibilita o seu resfriamento pela transferência de calor para o gel. A cada sessão, a aplicação era realizada em toda a área com poiquilodermia da região cervical anterior e laterais. Os disparos foram feitos imediatamente adjacentes um ao outro. Para a aplicação, os pacientes permaneciam na posição supina. Ambos, paciente e pesquisador, faziam uso de óculos de proteção durante as aplicações (Sliney, 1997) (Figura 3). 


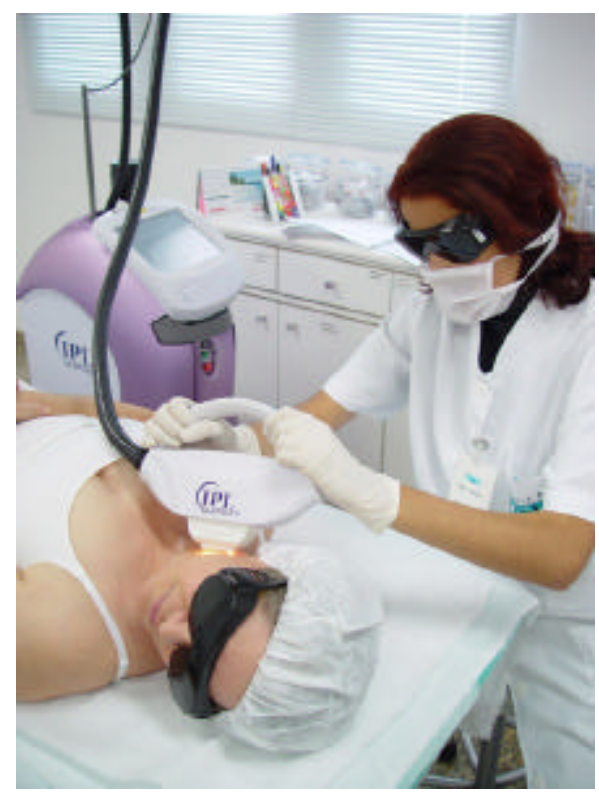

Figura 3. Aplicação da luz intensa pulsada

Para alívio do eritema e do edema decorrentes da aplicação, os pacientes eram orientados a fazerem compressas geladas. Nos casos de ruptura da integridade epidérmica e/ou formação de crostas, eram orientados a utilizarem creme com mupirocina a $2 \%$ duas vezes ao dia.

Entre as sessões os pacientes foram instruídos a utilizarem medidas de fotoproteção, como evitar exposição direta ao sol e usar bloqueador solar.

\section{5- Acompanhamento pós-pesquisa}

Ao final do estudo os pacientes seguiram em acompanhamento clínico nos seus respectivos ambulatórios de origem. 
Em caso de persistência das alterações de forma inestética e com possibilidade de resposta com mais sessões, era oferecido ao paciente a possibilidade de correção após o controle fotográfico e a biópsia.

\section{6- Critérios de avaliação clínica}

3.6.1- Avaliação dos resultados

A avaliação final dos resultados foi feita com base na comparação das imagens obtidas antes com as obtidas depois do tratamento. Esta avaliação foi feita por cinco observadores independentes, todos médicos com formação em dermatologia. As imagens foram analisadas diretamente no monitor do computador (Studioworks 441, LG Eletronics USA Inc. Englewood Cliffs, NJ, USA), sendo pareadas as imagens pré e póstratamento. Para cada paciente, colocavam-se as imagens lado a lado seqüencialmente nas três posições tomadas (cervical anterior, lateral esquerda e lateral direita), sempre as imagens pré-tratamento no lado esquerdo do monitor e as imagens pós-tratamento no lado direito do monitor. Os observadores, antes de iniciar a avaliação, liam uma folha contendo instruções sobre como transcorreria o processo. (Anexo C) Foram orientados a avaliar somente a região cervical, e não o tórax ou a face, os quais não receberam tratamento.

Considerando-se que havia variações quanto à predominância do componente vascular e/ou pigmentar entre os pacientes, bem como da 
resposta destes componentes ao tratamento, os resultados foram avaliados separadamente e incluiu-se a categoria "não destacado" quando o componente sob avaliação não era proeminente. Ambos os componentes vascular e pigmentar foram quantificados de acordo com a classificação proposta por Weiss et al. (2002) em 4 categorias: "pior", "inalterado", "pouco melhor" (melhora inferior a 50\%) e "muito melhor" (melhora superior a 50\%). Nos casos em que ocorria melhora em uma região e não na outra, os avaliadores foram orientados a classificar como "pouco melhor" ou "muito melhor", considerando-se o entendimento de que o tratamento foi capaz de proporcionar melhora.

Os critérios morfológicos utilizados para a avaliação do componente vascular foram a presença de eritema difuso e de telangiectasias e para a avaliação do componente pigmentar foi a presença de pigmentação acastanhada nas regiões avaliadas.

Os resultados apresentados correspondem à compilação das avaliações dos cinco observadores.

\subsection{2- Avaliação dos efeitos colaterais}

A avaliação dos efeitos colaterais do tratamento foi feita primeiramente pela observação das reações ocorridas imediatamente após cada aplicação. A partir da segunda sessão, pelo registro das reações relatadas pelos pacientes e pela observação das reações decorrentes da sessão anterior. 
Quando presentes, procurava-se determinar a sua duração, isto é, o tempo transcorrido desde o seu surgimento até a sua involução.

\section{7- Critérios de avaliação histopatológica}

Os cortes histológicos foram sistematicamente avaliados pelo pesquisador com o auxílio de um médico anátomo-patologista, para esclarecimento de dúvidas sobre os critérios analisados. A análise foi feita de forma cega afim de se evitar interpretação tendenciosa dos dados. Somente ao final da leitura de todas as lâminas revelaram-se quais eram os casos pré e pós-tratamento.

\subsection{1- Coloração pela hematoxilina e eosina (HE)}

Nos cortes corados pela hematoxilina e eosina foram analisados os seguintes achados histológicos: hiperceratose, retificação da epiderme, degeneração hidrópica dos queratinócitos basais, zona grenz subepidérmica, proliferação vascular e hiperplasia de glândulas sebáceas, identificando-se para cada um dos casos a presença ou ausência destes achados. Para as alterações histológicas representadas por degeneração basofílica do tecido conjuntivo e infiltrado inflamatório, além da observação de sua presença ou ausência no tecido, estas foram graduadas em leve, moderada ou intensa. 
3.7.2- Método de morfometria com análise de imagens por computador

As quantificações histológicas subjetivas têm a desvantagem do viés dos observadores pois são dependentes do olho humano, desta forma com muitas limitações em acurácia e reprodutibilidade. A análise das imagens por computador possibilita medidas mais objetivas, superando alguns destes inconvenientes. Desta forma, pode ser uma ferramenta útil no diagnóstico e comparação de diferenças em distúrbios da pigmentação, pela quantificação do pigmento melânico ou melanócitos nos cortes histológicos. (Lee et al., 2001) Também possibilita outras quantificações, como por exemplo de fibras elásticas, o que foi realizado no estudo de Brawan et al. (1991), cujo método foi utilizado neste estudo e será descrito a seguir.

Para as medições da quantidade de fibras elásticas, pigmento melânico e área do lúmen dos vasos utilizou-se o programa "Image-Pro Plus 4.1 for Windows" (Media Cybernetics - Silver Spring, Md, USA). As imagens selecionadas no microscópio óptico (Leica DMLS, Leica Mikroskopie und systeme GmbH - Wetzlar, Germany) eram captadas por uma câmera fotográfica acoplada (Pixera visual communication system - Version 2.0 for Windows 95; Pixera Corporation - Los Gatos, Ca, USA) sendo então transferidas ao microcomputador (Pentium II Processor, Intel Technology, IBM - USA) com o programa. No computador foram salvas as imagens digitalizadas capturadas. 


\subsection{3- Coloração para fibras elásticas}

As fibras elásticas foram avaliadas através da coloração resorcinafucsina de Weigert com oxidação (Cota-Pereira et al., 1976). Para cada caso estudado examinou-se uma lâmina de fragmento de pele antes do tratamento e uma lâmina de fragmento de pele depois do tratamento. Em cada lâmina foi realizada captura de cinco campos aleatórios com objetiva de 40x na derme justa-epidérmica e na derme profunda adjacente, correspondendo respectivamente, à derme papilar e à reticular.

As fibras elásticas coradas foram quantificadas em relação à sua área através do sistema de leitura de imagens por computador. Inicialmente eram delimitados os campos a serem examinados através da ferramenta de traço livre. Este recurso permite a eliminação de áreas indesejáveis como, por exemplo, as cristas epidérmicas ou artefatos de coloração. (Figura 4A) Dentro destes campos, eram apontadas pelo observador as cores a serem contadas, neste caso os tons de roxo das fibras elásticas. O programa identificava todas as vezes que aqueles tons apontados ocorriam nos campos selecionados por contraste de cor (densitometria digital) marcando então com a cor vermelha. (Figura 4B) Obtinha-se a soma das áreas identificadas pela cor vermelha em micrômetros quadrados $\left(\mu^{2}\right)$. Posteriormente obtinha-se a área total, isto é, a área ocupada pelas fibras somada à área entre as fibras, para se calcular a relação da densidade das fibras. (Figura 4C) 
Em ambas as profundidades, derme papilar e reticular, mediram-se a soma das áreas ocupadas pelas fibras elásticas em relação à área total de derme selecionada. Os valores apresentados em cada profundidade correspondem à média das cinco medidas. 

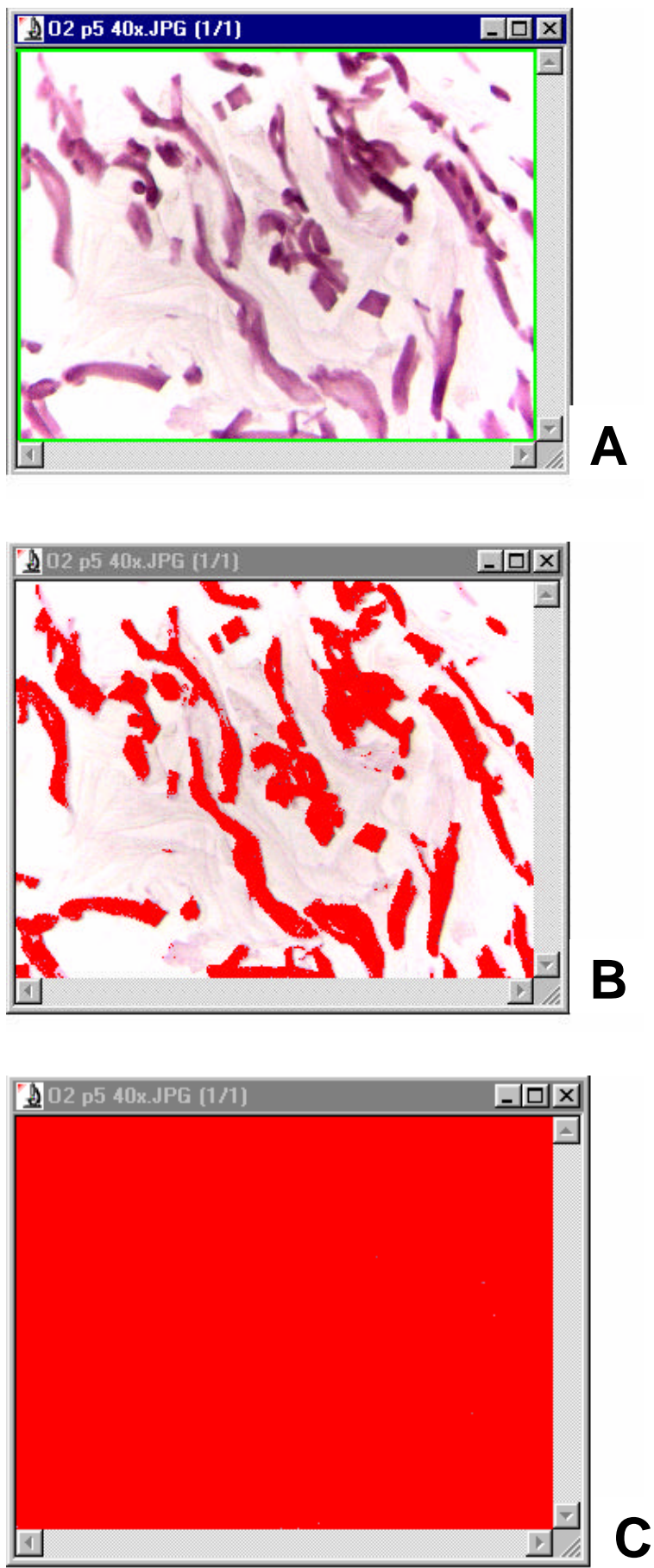

Figura 4. A: Fibras elásticas coradas pelo Weigert. com oxidação. Área de derme a ser medida selecionada com traço verde; B: Fibras elásticas marcadas em vermelho; C: Área total de derme selecionada marcada em vermelho 
3.7.4- Coloração para pigmento melânico

A análise do pigmento melânico foi feita através da coloração pelo Fontana Masson (Masson, 1928), utilizando-se a objetiva de 40x.

Para cada lâmina, foram obtidas medidas de cinco campos aleatórios na epiderme e na derme, e calculada a média das áreas ocupadas pelo pigmento melânico. De forma similar, examinou-se uma lâmina de fragmento de pele pré e uma de pós-tratamento para cada paciente.

A melanina foi quantificada na epiderme e na derme justaepidérmica de forma similar às fibras elásticas, pelo sistema de leitura de imagens por computador. (Figuras 5A-C) Em ambas as regiões, quantificaram-se a soma das áreas ocupadas pelo pigmento melânico em relação à área total medida. $\mathrm{Na}$ epiderme, os campos selecionados se extendiam da membrana basal até a camada granulosa. 

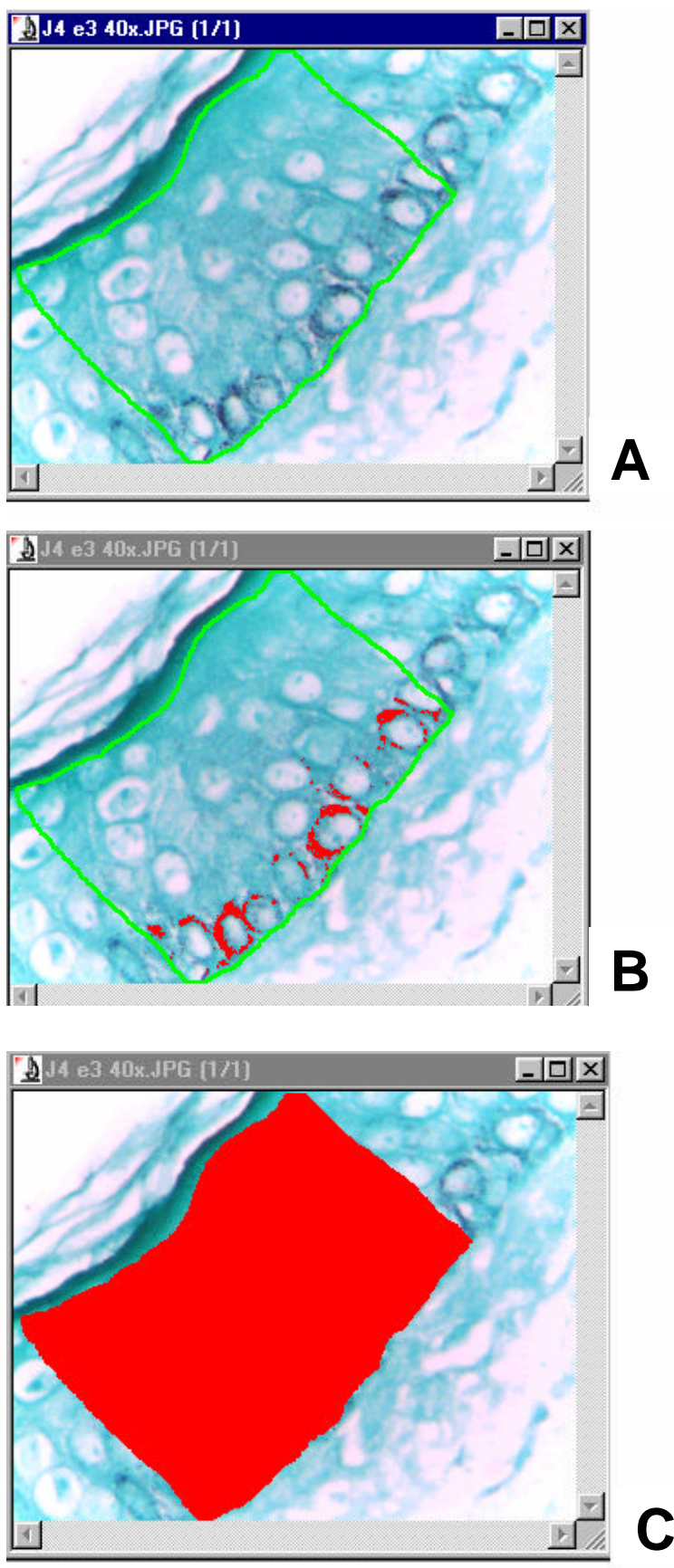

Figura 5. A: Pigmento melânico corado pelo Fontana Masson. Área de epiderme a ser medida selecionada com traço verde; B: Pigmento melânico marcado em vermelho; C: Área total de epiderme selecionada marcada em vermelho 


\subsection{5- Técnica imunohistoquímica}

A identificação dos vasos na derme foi feita através da técnica imunohistoquímica que utilizou como marcador o anticorpo monoclonal antiCD34 (NOVOCASTRA, UK, cód. 121203), que reconhece células endoteliais (Graham et al., 1994). Utilizou-se o método streptavidina-biotina-peroxidase (Hsu et al., 1981) segundo a técnica descrita a seguir.

Cortes histológicos de $4 \mu \mathrm{m}$ de espessura foram obtidos a partir de material embebido em parafina e colhidos em lâminas previamente preparadas com solução adesiva de 3 amino-propyltriethoxy-silane (SIGMA Chemical Co., St. Louis, MO/USA, cód. A3648) e acondicionadas em estufa a $56-58^{\circ} \mathrm{C}$ por 48 horas. A seguir, foram desparafinados em dois banhos de xilol a $56^{\circ} \mathrm{C}$ durante 30 minutos e à temperatura ambiente durante 20 minutos, sendo posteriormente hidratados em seqüência decrescente de etanol $(100 \%, 95 \%$ e $70 \%)$ e água corrente durante cinco minutos cada. Para a quebra das ligações aldeídicas provocadas pela fixação em formalina, fez-se a exposição antigênica com tampão citrato (solução de ácido cítrico $0,01 \mathrm{M}, \mathrm{pH} 6,0$ ) no forno de microondas na potência máxima por 10 minutos e então deixou-se esfriar por 20 minutos à temperatura ambiente. O bloqueio de peroxidase endógena foi feito em câmara escura com duas trocas em solução aquosa de peróxido de hidrogênio 3\% por 10 minutos cada, sendo em seguida as lâminas lavadas por 10 minutos em água corrente e por 5 minutos em água destilada com tampão TRIS (hidroximetil aminometano, LABSYNTH Ltda, Diadema/SP/BR, cod T1033). A etapa 
seguinte constituiu-se da incubação dos cortes com o anticorpo anti-CD34 humano produzido em camundongo na diluição de 1:1000 em solução de albumina bovina fração V (SERVA, cód. 11930) "overnight" a 4ํㅡ. Procedeuse com a lavagem em tampão, duas trocas de cinco minutos cada e a incubação com o anticorpo secundário anti-camundongo biotinelado (DAKO Strepto-ABC-Complex/HRP duet mouse/rabit, cód K0492) e em seguida com - complexo estreptavidina-biotina peroxidase (DAKO StreptoABCComplex/HRP duet mouse/rabit, cód K0492), ambos por 60 minutos a $37^{\circ} \mathrm{C}$. Antes e após cada incubação fez-se duas lavagens com solução tampão por cinco minutos. Revelou-se a reação com solução cromógena de diaminobenzidina (3,3'- diaminobenzidine, SIGMA Chemical Co., St. Louis, MO/USA, cód. D5637) 0,03\% acrescida de 1,2 $\mathrm{ml}$ de água oxigenada $3 \%$, por até 5 minutos. O controle da coloração foi feito sob observação ao microscópio óptico. Os cortes histológicos foram lavados em água corrente por 10 minutos, contracorados com hematoxilina de Harris por 30 segundos, lavados em água corrente, desidratados em etanol e diafanizados em xilol. A montagem das lâminas foi feita com resina Permount (FISHER Scientific, Fair Lawn, NJ/USA, cód. SP15-100).

\subsection{6- Análise dos vasos}

Realizou-se a contagem do número de vasos corados pelo anticorpo anti-CD34 na derme superficial e profunda nos cortes pré e pós-tratamento. Sob magnificação de 400x, realizou-se a contagem do número de vasos sob 
a área de um gratículo de 0,0625 $\mathrm{mm}^{2}$. Foram contados campos aleatórios, no total de cinco campos na derme superficial e cinco campos na derme profunda correspondente, e obtida a média.

Realizou-se ainda, através do método de análise de imagens por computador, a medida das áreas dos lúmens dos vasos na derme superficial e profunda. Em cada profundidade, a medição foi feita em cinco campos, calculando-se a média das áreas. (Figuras 6A-B)

A

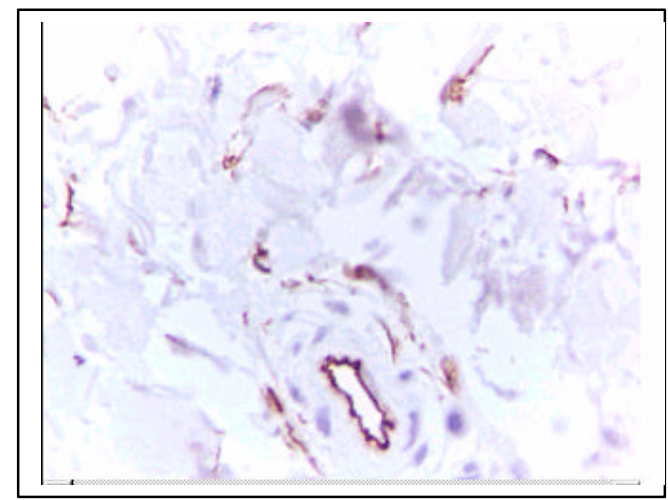

B

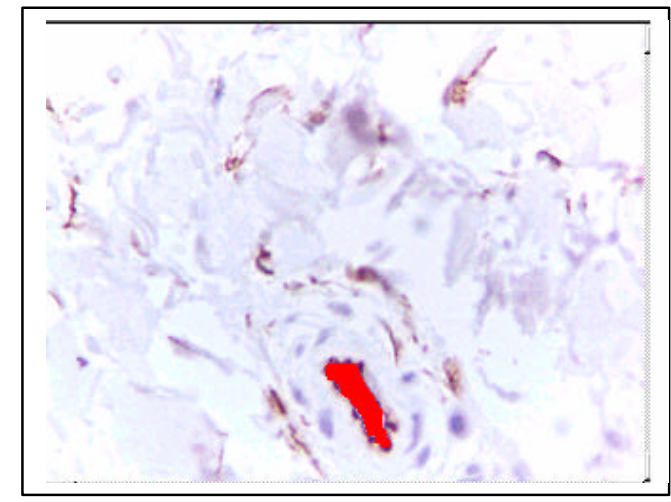

Figura 6. A: Marcação imunohistoquímica do endotélio vascular com anticorpo anti-CD34; B: Lúmen do vaso marcado para cálculo da área 


\section{8- Método estatístico}

Para a análise dos resultados foram utilizados os seguintes testes:

1- Teste de Kappa (Landis, Kock, 1977) - Para estudar as concordâncias e as discordâncias (Teste de McNemar) em relação às variáveis estudadas.

2- Teste de Wilcoxon (Siegel, Castellan Jr, 1988) - Com a finalidade de comparar os mesmos indivíduos em dois momentos do estudo.

Fixou-se em 0,05 ou $5 \%$ o nível de rejeição da hipótese de nulidade assinalando-se com asterisco os valores significantes. Em alguns casos adotou-se o nível de $5 \%$ em termos de teste monocaudal $(Z$ crítico $=1,64)$. Para os testes bicaudais o Z crítico foi de 1,96. 


\section{4- RESULTADOS}

\section{1- Dados epidemiológicos}

Os pacientes relataram tempo de evolução da PC bastante variáveis que foram de 6 meses a 20 anos (média 8 anos). A presença em outros membros da família foi referida por 12 dos 16 pacientes. A utilização prévia ou atual de produtos na região cervical foi confirmada por 12 pacientes, os quais consistiram de perfumes por sete pacientes, cremes hidratantes por sete pacientes e loção pós-barba por um paciente. Em relação à utilização de filtro solar na região cervical, nove pacientes referiram usar, dos quais três haviam iniciado o uso apenas 30 dias antes da entrevista. Nove pacientes do sexo feminino não trabalhavam e entre os sete pacientes que trabalhavam, as profissões eram exercidas em ambiente fechado (executivo, dentista, farmacêutica, professora, vendedoras, empregada doméstica). A ocorrência da menopausa foi referida por 6 pacientes, sendo cirúrgica em duas destas.

\section{2- Dados clínicos}

Além do envolvimento da região cervical, todos os pacientes apresentavam o quadro no tórax anterior, e em três pacientes também havia envolvimento da face. 
Do grupo inicial de 16 pacientes, apenas um não completou o estudo, tendo sido perdido o contato após a quarta sessão.

4.2.1- Avaliação fotográfica dos resultados

As avaliações de cada observador encontram-se descritas nas tabelas 1 e 2, que demonstram, respectivamente, os componentes vascular e pigmentar.

Tabela 1 - Avaliação da resposta clínica do componente vascular da poiquilodermia de Civatte, através das fotografias antes e após o tratamento com luz intensa pulsada, realizada por cinco observadores

\begin{tabular}{lccccc}
\hline Observadores & $\mathbf{1}$ & $\mathbf{2}$ & $\mathbf{3}$ & $\mathbf{4}$ & $\mathbf{5}$ \\
\hline Paciente 1 & $\mathrm{MM}$ & $\mathrm{MM}$ & $\mathrm{PM}$ & $\mathrm{PM}$ & $\mathrm{PM}$ \\
Paciente 2 & $\mathrm{ND}$ & $\mathrm{MM}$ & $\mathrm{PM}$ & $\mathrm{PM}$ & $\mathrm{PM}$ \\
Paciente 3 & $\mathrm{MM}$ & $\mathrm{MM}$ & $\mathrm{MM}$ & $\mathrm{MM}$ & $\mathrm{MM}$ \\
Paciente 4 & $\mathrm{MM}$ & $\mathrm{MM}$ & $\mathrm{MM}$ & $\mathrm{MM}$ & $\mathrm{MM}$ \\
Paciente 5 & $\mathrm{PM}$ & $\mathrm{NA}$ & $\mathrm{MM}$ & $\mathrm{PM}$ & $\mathrm{MM}$ \\
Paciente 6 & $\mathrm{MM}$ & $\mathrm{MM}$ & $\mathrm{MM}$ & $\mathrm{MM}$ & $\mathrm{MM}$ \\
Paciente 7 & $\mathrm{MM}$ & $\mathrm{MM}$ & $\mathrm{MM}$ & $\mathrm{MM}$ & $\mathrm{MM}$ \\
Paciente 8 & $\mathrm{PM}$ & $\mathrm{PM}$ & $\mathrm{MM}$ & $\mathrm{MM}$ & $\mathrm{PM}$ \\
Paciente 9 & $\mathrm{MM}$ & $\mathrm{MM}$ & $\mathrm{MM}$ & $\mathrm{MM}$ & $\mathrm{MM}$ \\
Paciente 10 & $\mathrm{ND}$ & $\mathrm{MM}$ & $\mathrm{MM}$ & $\mathrm{MM}$ & $\mathrm{PM}$ \\
Paciente 11 & $\mathrm{MM}$ & $\mathrm{PM}$ & $\mathrm{MM}$ & $\mathrm{MM}$ & $\mathrm{PM}$ \\
Paciente 12 & $\mathrm{MM}$ & $\mathrm{MM}$ & $\mathrm{MM}$ & $\mathrm{MM}$ & $\mathrm{PM}$ \\
Paciente 13 & $\mathrm{NA}$ & $\mathrm{MM}$ & $\mathrm{MM}$ & $\mathrm{MM}$ & $\mathrm{NA}$ \\
Paciente 14 & $\mathrm{PM}$ & $\mathrm{MM}$ & $\mathrm{NA}$ & $\mathrm{PM}$ & $\mathrm{PM}$ \\
Paciente 15 & $\mathrm{PM}$ & $\mathrm{NA}$ & $\mathrm{PM}$ & $\mathrm{P}$ & $\mathrm{PM}$ \\
\hline
\end{tabular}

NOTA: ND=não destacado; $\mathrm{P}=$ pior; $\mathrm{NA}=$ não alterou; $\mathrm{PM}=$ pouco melhor; $\mathrm{MM}=$ muito melhor 
Tabela 2 - Avaliação da resposta clínica do componente pigmentar da poiquilodermia de Civatte, através das fotografias antes e após o tratamento com luz intensa pulsada, realizada por cinco observadores

\begin{tabular}{lccccc}
\hline Observadores & $\mathbf{1}$ & $\mathbf{2}$ & $\mathbf{3}$ & $\mathbf{4}$ & $\mathbf{5}$ \\
\hline Paciente 1 & ND & ND & PM & PM & ND \\
Paciente 2 & NA & NA & NA & NA & P \\
Paciente 3 & PM & PM & NA & MM & ND \\
Paciente 4 & ND & ND & PM & ND & ND \\
Paciente 5 & ND & ND & NA & MM & ND \\
Paciente 6 & NA & PM & PM & MM & PM \\
Paciente 7 & PM & ND & MM & MM & PM \\
Paciente 8 & P & PM & MM & MM & ND \\
Paciente 9 & ND & PM & PM & MM & ND \\
Paciente 10 & PM & ND & MM & PM & ND \\
Paciente 11 & ND & ND & PM & PM & ND \\
Paciente 12 & ND & PM & PM & MM & ND \\
Paciente 13 & ND & MM & MM & MM & ND \\
Paciente 14 & PM & PM & NA & PM & PM \\
Paciente 15 & NA & NA & NA & NA & NA \\
\hline NOTA: ND=não destacado; P=pior: NA=não alterou; PM=pouco melhor: MM=muito melhor
\end{tabular}

Considerando a predominância do componente vascular e/ou pigmentar nos pacientes estudados, observou-se que em maior número de casos $(30,66 \%)$ o componente pigmentar não foi distinguível em relação ao componente vascular comparando-se à situação inversa (2,66\%), tendo sido classificado como "não destacado". (Tabela 3)

A avaliação clínica final dos 15 pacientes pelos cinco avaliadores mostrou, em relação ao componente vascular, que na grande maioria dos casos $(89,33 \%)$ houve melhora deste após o tratamento. O componente 
pigmentar já mostrou uma distribuição menos evidente da sua resposta clínica ao tratamento, sendo que houve muita melhora em $18,66 \%$ dos casos, pouca melhora em $25,33 \%$ dos casos e não houve alteração em $20 \%$ dos casos. Como já mencionado, em $30,66 \%$ dos casos, não foi possível avaliar as modificações, pois este componente não se destacava em relação ao componente vascular (Tabela 3).

Tabela 3 - Porcentagem de casos de poiquilodermia de Civatte tratados com luz intensa pulsada, segundo escores de resposta clínica dos componentes vascular e pigmentar, avaliados por cinco observadores a partir das fotografias de 15 pacientes

\begin{tabular}{cccccc}
\hline Critérios & $\begin{array}{c}\text { Não } \\
\text { destacado }\end{array}$ & Pior & $\begin{array}{c}\text { Não } \\
\text { alterado }\end{array}$ & $\begin{array}{c}\text { Pouco } \\
\text { melhor }\end{array}$ & $\begin{array}{c}\text { Muito } \\
\text { melhor }\end{array}$ \\
\hline $\begin{array}{c}\text { Componente } \\
\text { vascular }\end{array}$ & $2,66 \%$ & $1,33 \%$ & $6,66 \%$ & $28 \%$ & $61,33 \%$ \\
$\begin{array}{c}\text { Componente } \\
\text { pigmentar }\end{array}$ & $30,66 \%$ & $5,33 \%$ & $20 \%$ & $25,33 \%$ & $18,66 \%$ \\
\hline
\end{tabular}

A opinião dos avaliadores mostrou que o componente vascular tende a evoluir melhor do que o componente pigmentar, o que foi confirmado pela significância na análise estatística $(p<0,001)$ (Anexo D, Tabela 5).

As figuras 7A-D estão demonstrando em um caso a evolução da resposta clínica ao tratamento após a realização de duas, quatro e cinco sessões. 
A

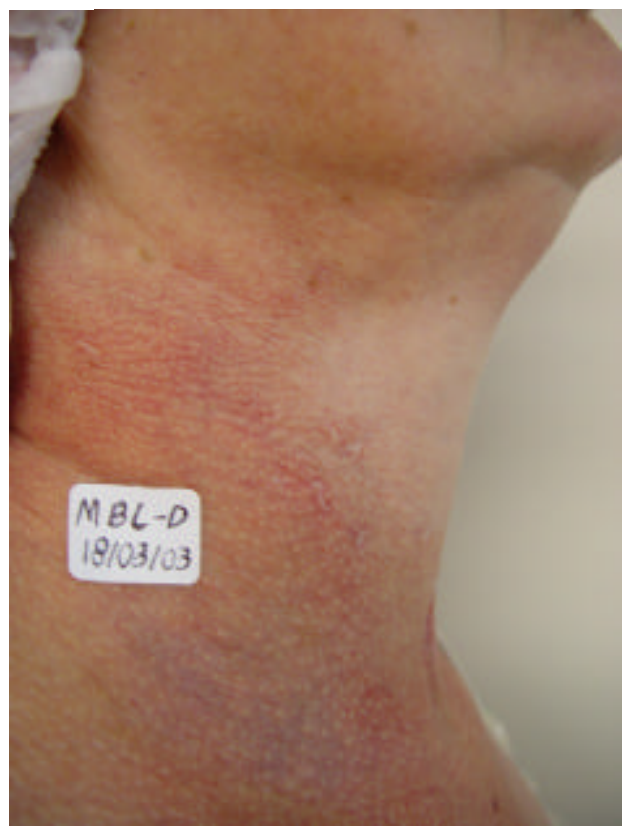

C

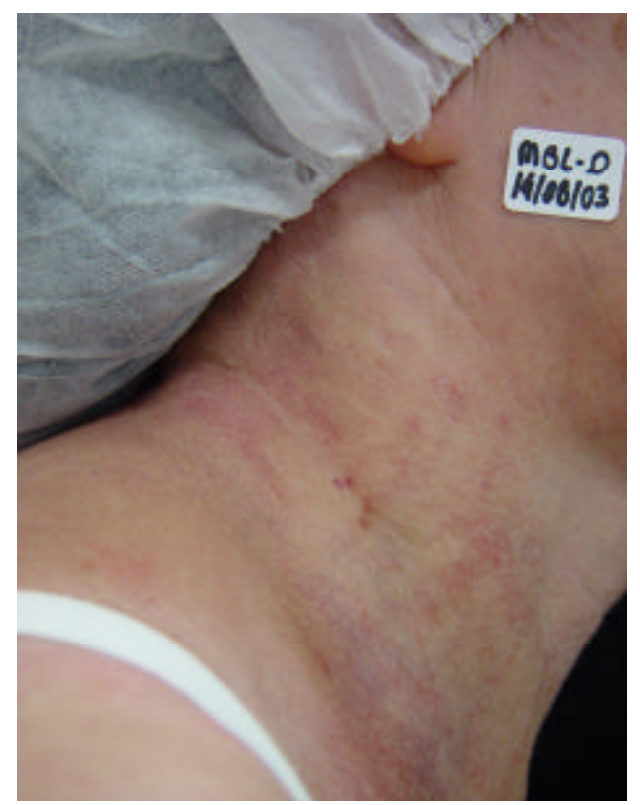

B

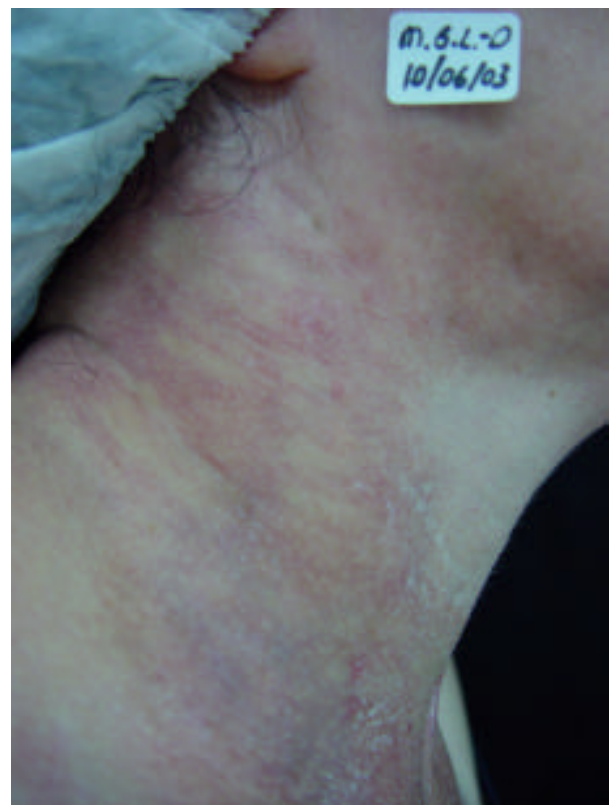

D

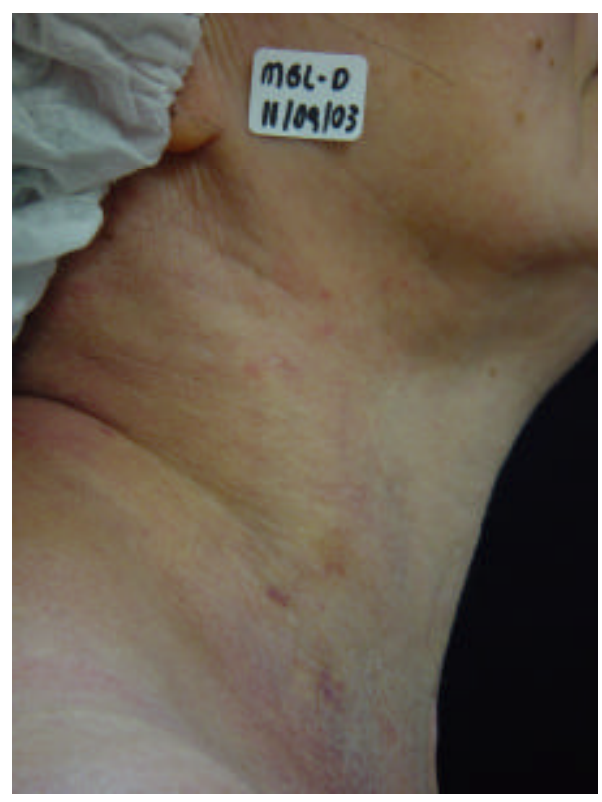

Figura 7. A: Paciente com poiquilodermia de Civatte na regiao cervical antes do tratamento com luz intensa pulsada; B: Após 2 sessões; C: Após 4 sessões; D: Após 5 sessões. 


\subsection{2- Avaliação dos efeitos colaterais}

Para todos os efeitos descritos, foram considerados quando ocorriam em pelo menos uma das cinco sessões a que o paciente foi submetido. Estes efeitos sobrevieram habitualmente em áreas localizadas, com o formato retangular da ponteira.

Entre as reações observadas imediatamente após cada aplicação, cita-se o desenvolvimento de eritema em todos os pacientes e edema na maioria dos pacientes (Figura 8; Tabela 4). Em quatro pacientes, imediatamente após a aplicação, pôde-se observar o desenvolvimento de púrpura, e em seis pacientes pôde-se notar ruptura da integridade epidérmica associada à alteração da cor da pele, que se tornava acinzentada.

A formação de crostas acastanhadas foi observada em 14 pacientes, em pelo menos uma das sessões. Após a descamação das crostas, notavase o clareamento da área, que normalmente ocorria também no formato da ponteira, deixando em alguns casos $(n=3)$ um aspecto lembrando listras pela persistência de áreas lineares não tratadas. Em uma paciente houve desenvolvimento de hiperpigmentação pós-inflamatória após a quinta sessão. Não puderam ser avaliadas a duração da hiperpigmentação e das áreas lineares não tratadas, considerando-se que a última avaliação foi feita 30 dias após a quinta sessão, e neste período ambas ainda permaneciam. 
A

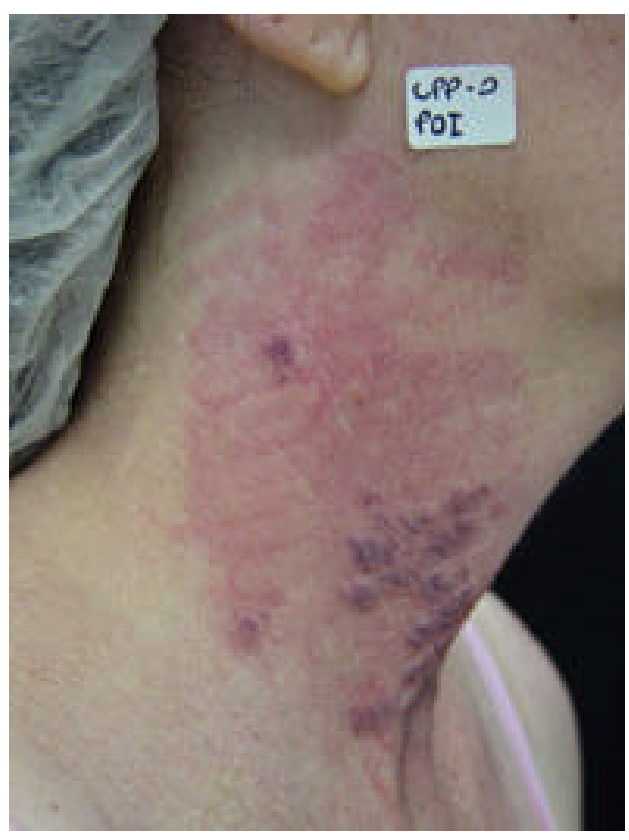

C

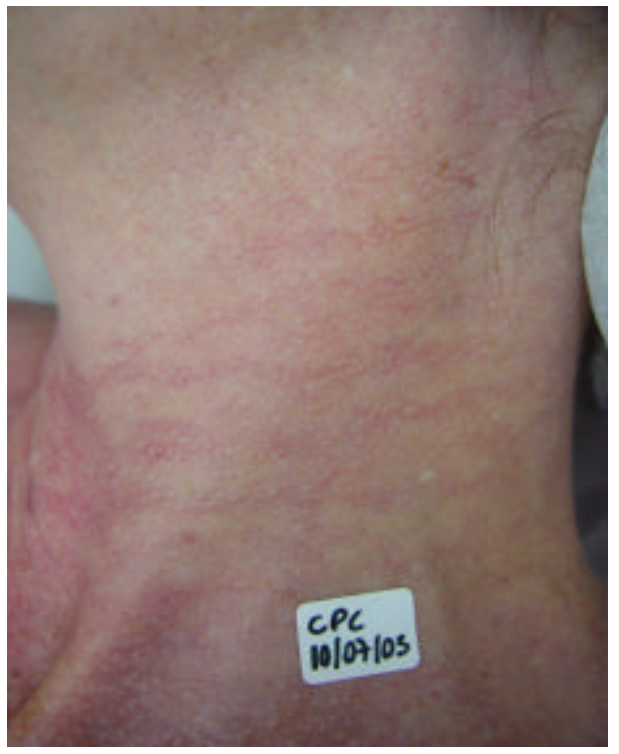

B

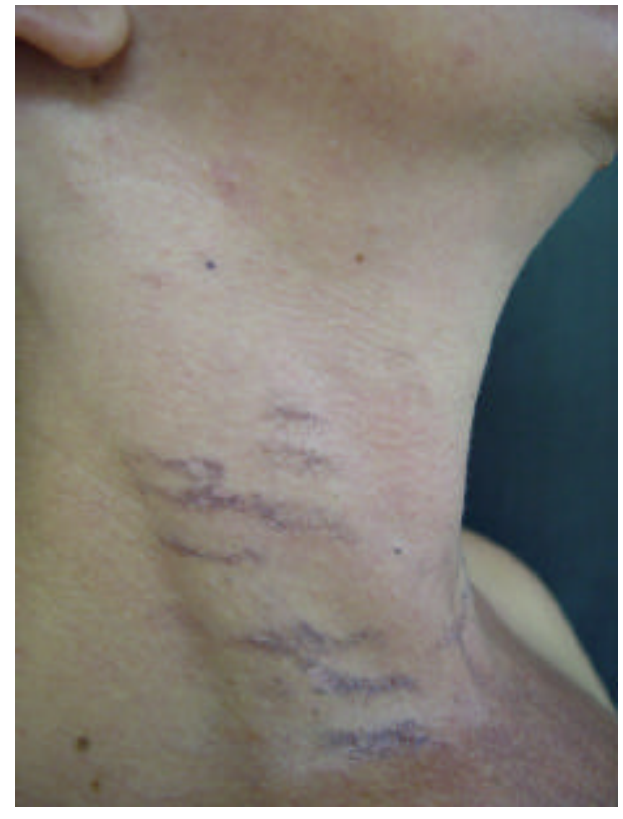

D

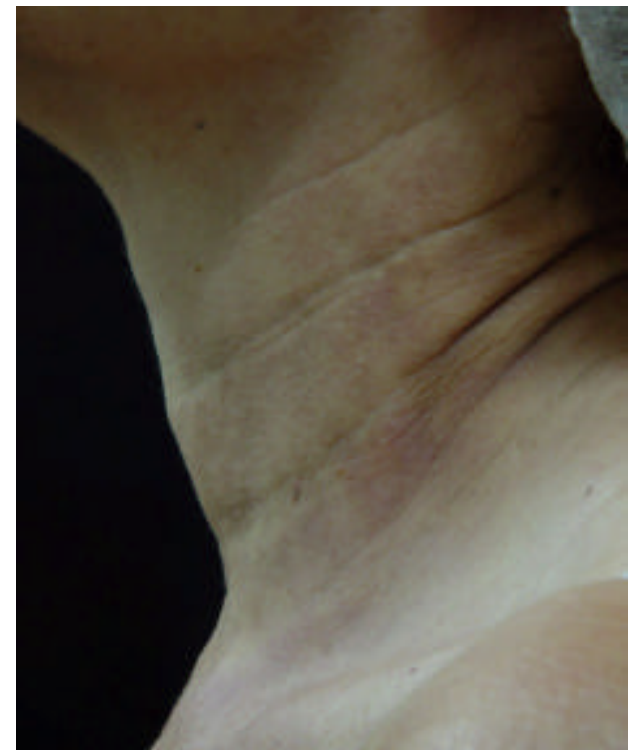

Figura 8. Efeitos colaterais observados após a utilização da luz intensa pulsada para o tratamento da poiquilodermia de Civatte na região cervical. A: Eritema, edema e púrpura; B: Crostas; C: Persistência de áreas lineares não tratadas; D: Hiperpigmentação pós-inflamatória 
Tabela 4 - Efeitos colaterais e tempo médio para resolução em dias, nos 15 pacientes portadores de poiquilodermia de Civatte na região cervical tratados com luz intensa pulsada, observados em pelo menos uma das cinco sessões

\begin{tabular}{lcc}
\hline \multicolumn{1}{c}{ EFEITO COLATERAL } & $\begin{array}{c}\text { NÚMERO DE } \\
\text { PACIENTES }\end{array}$ & $\begin{array}{c}\text { TEMPO MÉDIO } \\
\text { PARA RESOLUÇÃO } \\
\text { (DIAS) }\end{array}$ \\
\hline Eritema & 15 & 3 \\
Edema & 10 & 2 \\
Púrpura & 4 & 7 \\
Ruptura da integridade epidérmica & 6 & 10 \\
Crostas & 14 & 10 \\
Áreas lineares não tratadas & 3 & $\ldots$ \\
Hiperpigmentação pós-inflamatória & 1 & $\ldots$ \\
\hline
\end{tabular}

Em um caso em que a persistência de áreas lineares não tratadas ocasionou um aspecto inestético à paciente, realizou-se após a biópsia e o controle fotográfico, uma sessão extra para correção das áreas remanescentes, com melhora do aspecto final.

\section{3- Dados histopatológicos}

\subsection{1- Coloração pela hematoxilina e eosina}

$\mathrm{Na}$ análise histopatológica através da coloração com hematoxilina e eosina, os parâmetros classificados com os critérios presente ou ausente (hiperceratose, retificação da epiderme, degeneração hidrópica dos queratinócitos basais, zona grenz, proliferação vascular, hiperplasia de glândulas sebáceas), não mostraram alterações notáveis (Anexo D, Tabelas $6,7,8,9,10$ e 11). Entre os parâmetros graduados como leve, moderado ou 
intenso (degeneração basofílica do tecido conjuntivo, infiltrado inflamatório), também não houveram modificações significantes (Anexo D, Tabelas 12 e 13).

\subsection{2- Resorcina-Fucsina de Weigert com oxidação}

$\mathrm{Na}$ coloração pelo Weigert com oxidação, não houve alteração com significância estatística na densidade das fibras elásticas na derme superficial e na derme profunda. A variação dos valores do pré-tratamento em relação ao pós-tratamento $(\Delta \%)$ também não mostrou diferença significativa na derme superficial em relação à derme profunda (Anexo $D$, Tabela 14).

\subsection{3- Coloração pelo Fontana Masson}

A coloração pelo Fontana Masson mostrou, na epiderme, uma redução significativa $(p=0,0446)$ na quantidade de pigmento melânico. $\mathrm{Na}$ derme não se observou redução. A variação dos valores pré-tratamento e pós-tratamento $(\Delta \%)$ não foi significativa na epiderme em relação à derme (Anexo D, Tabela 15). Observou-se que houve aumento discrepante na quantidade de pigmento melânico nos casos pós-tratamento, na epiderme do paciente 12 e na derme do paciente 15. Apesar de os casos pré e póstratamento terem sido corados na mesma ocasião, nestes dois pacientes houve maior impregnação do corante nos casos pós-tratamento, o que provocou precipitação deste em alguns locais, justificando os valores bastante aumentados. Realizaram-se os cálculos estatísticos excluindo-se 
estes dois casos, porém mantiveram-se os valores de significância e não significância na epiderme e derme, respectivamente (Anexo D, Tabela 16).

4.3.4- Marcação imunohistoquímica com o anticorpo anti-CD34

A contagem do número de vasos pela marcação imunohistoquímica pelo anticorpo anti-CD34 não se alterou de forma estatisticamente significante na derme superficial e profunda. Da mesma forma, a variação dos valores antes e após o tratamento $(\Delta \%)$ entre a derme superficial e profunda não foi significativa (Anexo $D$, Tabela 17). A medida da média da área do lúmen dos vasos não mostrou redução na derme superficial e profunda. A variação dos valores pré e pós-tratamento $(\Delta \%)$ entre a derme superficial e profunda também não foi significativa (Anexo D, Tabela 18). 


\section{5- DISCUSSÃO}

Em relação aos dados epidemiológicos coletados nas entrevistas, as informações estão de acordo com as descrições da literatura, em que a história familiar positiva esteve presente (12 de 16 pacientes) indicando a predisposição genética da condição; assim como a utilização de cosméticos na região cervical (12 de 16 pacientes), de acordo com os estudos que sugerem que estes podem ter papel no desencadeamento e manutenção da PC. É interessante notar que nenhum paciente possuía profissão exercida diretamente em ambiente aberto, o que pode indicar que outros fatores além da exposição crônica ao sol podem ter influência na ocorrência da PC, como descrito na literatura (Duarte, 1996; Katoulis et al., 1999; Sahoo, Kumar, 2001; Katoulis et al., 2002). Nos demais dados da anamnese não houveram informações relevantes.

A LIP tem se mostrado uma opção válida para o tratamento da PC, pelos bons resultados que apresenta, associados à baixa ocorrência de efeitos colaterais (Raulin et al., 1997b; Schroeter, Neumann, 1998; Weiss et al., 2000; Goldman, Weiss, 2001). Isto pôde ser verificado neste estudo.

Em relação à resposta clínica, Schroeter e Neumann (1998), diferentemente dos outros autores que trataram a PC com LIP, apresentam os resultados, individualizando os componentes vascular e pigmentar. No presente estudo, também foi necessário distinguir esses dois componentes, 
pois se notou que responderam de forma diferente com a evolução do tratamento.

Os autores relataram, em 15 pacientes com PC tratados com LIP, clareamento de $90 \%$ do componente vascular e não mencionaram a resposta do componente pigmentar. Citaram clareamento de $80 \%$ sem especificar a que se referem, levando à suposição de que retratam o clareamento geral, o que indicaria que o clareamento do componente pigmentar foi inferior ao do componente vascular (Schroeter, Neumann, 1998). Da mesma forma, no atual estudo, ocorreu clareamento significativo do componente vascular, superior ao observado no componente pigmentar.

A resposta do componente pigmentar ao tratamento parece depender da profundidade em que o pigmento se encontra na pele. Em estudo que envolveu 20 pacientes com lesões melanocíticas tratadas com LIP, estas foram divididas em superficiais (manchas café-com-leite, efélides, melasma epidérmico e nevo epidérmico) e profundas (nevo de Becker, nevo spillus e melasma misto). As lesões superficiais foram tratadas com filtro de $590 \mathrm{~nm}$, e as profundas, com filtro de $615 \mathrm{~nm}$. O resultado foi melhor nas lesões superficiais. Os autores sugeriram que lesões com componente profundo poderiam necessitar de múltiplas sessões e/ou alta fluência (Arias, Ferrando, 2001). Considerando-se o exposto, a ocorrência de resultado inferior do componente pigmentar em relação ao componente vascular observada neste estudo, poderia ser atribuída ao filtro utilizado de $560 \mathrm{~nm}$, que tem uma penetração predominantemente mais superficial na pele. 
Comprimentos de onda entre 514 e 1060 nm têm uma penetração na pele entre 300 e $1600 \mu \mathrm{m}$ (Anderson, 1994). Considerando-se que na região cervical anterior a espessura da pele é de cerca de $1408.0 \pm 362.1 \mu \mathrm{m}$, isto indica que a luz, nos comprimentos de onda utilizados neste estudo, provavelmente foi capaz de penetrar toda a derme (Lee, Hwang; 2002). O fato de se utilizarem filtros que permitem a passagem dos comprimentos de onda mais curtos, faz com que estes atuem mais superficialmente, diminuindo a quantidade de energia que atinge as camadas mais profundas.

No estudo de Cymbalista (2004) em que tratou 12 pacientes com hipercromia cutânea idiopática da região orbital com duas a quatro sessões de LIP e avaliou clinicamente os pacientes 30 dias e 12 meses após a última sessão, observou em alguns pacientes melhora mais evidente na avaliação após 12 meses. A autora concluiu que alguns casos podem necessitar de um tempo maior de observação após o tratamento para haver clareamento ou para que a hiperpigmentação pós-inflamatória desapareça. O mesmo poderia ser entendido para o presente estudo quando, com o passar do tempo, talvez pudesse ser notado maior clareamento do componente pigmentar.

Os efeitos adversos observados neste estudo, em ordem decrescente de ocorrência foram de eritema (100\%), formação de crostas (93.3\%), edema $(66.7 \%)$, ruptura da integridade epidérmica (40\%), púrpura $(26.7 \%)$, persistência de áreas lineares não tratadas (20\%), e hiperpigmentação pósinflamatória (6.7\%). Todos estes achados já foram descritos na literatura acontecendo com diferentes freqüências, exceto a ruptura da integridade 
epidérmica, sobre a qual não foram encontradas citações, estando porém descrito em alguns artigos a ocorrência de bolhas (Schroeter, Neumann, 1998; Bitter, 2000; Raulin et al., 2003).

A hipopigmentação, também relatada em alguns estudos, não foi observada neste trabalho (Raulin et al., 1997b; Schroeter, Neumann, 1998; Weiss et al., 2000; Goldman, Weiss, 2001; Weiss et al., 2002). Foi descrita em quatro dentre 135 pacientes com PC tratados com LIP por Weiss et al. (2000), tendo persistido além de 2 anos em dois pacientes. Em outro estudo de Weiss et al. (2002), que tratou 80 pacientes na face, pescoço e tórax para fotorejuvenescimento com o Photoderm ${ }^{\circledR}$ VL, a hipopigmentação foi vista em 2,5\% dos pacientes, sendo que particularmente no pescoço.

A ocorrência de eritema e edema é descrita como típica entre os autores que realizaram o tratamento da região cervical, sendo relatada duração entre 24 e 72 horas (Raulin et al., 1997b; Weiss et al., 2000; Goldman, Weiss, 2001; Weiss et al., 2002). Formação de crostas foi citada nos artigos entre 5\% e 19\% dos pacientes, com remissão em 1 a 3 dias (Weiss et al., 2000; Weiss et al., 2002). Desenvolvimento de áreas localizadas de púrpura foi apontada com freqüências que variaram entre 6 e 22\% dos casos e duração entre 1 e 5 dias (Weiss et al., 2000; Goldman, Weiss, 2001; Weiss et al., 2002). A persistência de áreas lineares não tratadas foi descrita no estudo de Weiss et al. de 2000 , que referem ser de fácil correção através do posicionamento da ponteira sobre as áreas remanescentes. Nos achados deste estudo, observou-se que a ocorrência de crostas aconteceu com maior freqüência, assim como transcorreu maior 
tempo para sua regressão. Deve-se salientar novamente que estes efeitos colaterais foram considerados quando verificados em pelo menos uma das cinco sessões, sendo que muitas vezes ocorreu a formação de crostas em poucas áreas localizadas, com o formato da ponteira, provavelmente nos locais em que esta ficava mais próxima à pele no momento da aplicação.

No estudo de Raulin et al. (1997b), em que trataram com o Photoderm ${ }^{\circledR}$ VL telangiectasias essenciais e um caso de PC, os autores observaram hiperpigmentação transitória em dois de 14 pacientes, e associaram a sua ocorrência à utilização de altas fluências. Na paciente deste estudo que desenvolveu hiperpigmentação, esta ocorreu justamente após a sessão em que se utilizou a maior fluência $\left(30 \mathrm{~J} / \mathrm{cm}^{2}\right)$, e que esteve associada aos efeitos adversos mais intensos (ruptura da integridade epidérmica e crostas mais numerosas).

Segundo Raulin et al. (2003), a ocorrência de efeitos colaterais é mais freqüente nos pacientes com fototipos mais escuros e/ou naqueles com a pele bronzeada, pois a presença de maior quantidade de melanina vai determinar maior absorção da luz. Além destes, citam outros fatores que determinariam a ocorrência dos efeitos colaterais, entre eles o tônus da pele, a espessura da derme, o grau de sensibilidade e o número relativo de glândulas sebáceas nas várias partes do corpo. Os autores enfatizam, também, a importância da pele estar suficientemente resfriada durante a aplicação. No presente estudo, outro fator observado, que teve influência no desenvolvimento dos efeitos adversos foi a distância em que a ponteira foi posicionada em relação à pele no momento da aplicação. Isto foi visto uma 
vez que, em todos os casos deste estudo, os efeitos foram notados apenas em áreas localizadas e com o formato retangular da ponteira, estando os outros fatores como cor da pele, temperatura do gel e resfriamento da ponteira constantes. O fato da superfície do pescoço não ser plana, isto é, ter reentrâncias e saliências, faz com que a distância da ponteira em relação à pele sofra pequenas variações, que irão determinar a ocorrência dos efeitos colaterais descritos.

Os critérios para avaliação histopatológica qualitativa através da coloração com hematoxilina e eosina foram baseados na descrição de Duarte (1996), que biopsiou 79 pacientes com PC. Considerando-se tal descrição, neste estudo procurou-se avaliar se, após o tratamento com LIP, ocorriam modificações na hiperceratose, retificação da epiderme, degeneração hidrópica dos queratinócitos basais, degeneração basofílica do tecido conjuntivo, proliferação vascular, infiltrado inflamatório e hiperplasia de glândulas sebáceas. Além disto, acrescentou-se o critério zona grenz, baseado na afirmação de Fournier et al. (2001) de que em todos os processos de remodelação ou "resurfacing", espera-se que a zona grenz se espesse pelo aumento da deposição de colágeno, com reorganização em arranjos paralelos das fibrilas compactas. Afirma, porém, que este processo leva meses para ser visualizado após o procedimento.

Em todos os critérios avaliados através da coloração com HE, não foram observadas modificações significativas (Anexo D, Tabelas 6-13). Na literatura são encontrados resultados que diferem entre si, como já mencionados. Nos estudos que utilizaram a LIP para o tratamento do 
fotoenvelhecimento em que foi feita avaliação histopatológica, cita-se Bitter (2000) que em um caso, observou novo colágeno na derme, desaparecimento dos melanófagos e do infiltrado inflamatório dérmico superficial. Hernández-Pérez e lbiett (2002b) observaram na maioria dos casos tratados $(n=5)$, graus variados de melhora na atrofia, rolhas córneas, perda de polaridade, liquefação da camada basal, medida da espessura epidérmica, elastose, edema, telangiectasias e inflamação. Ao contrário, Prieto et al. (2002) em cinco pacientes, não observaram alterações nas estruturas epiteliais, incluindo a zona da membrana basal bem como na quantidade e qualidade das fibras colágenas, elásticas e de reticulina antes e após o tratamento.

Os autores afirmam que os diferentes resultados relatados com a utilização da LIP podem ser decorrentes de diferenças nas técnicas empregadas, como a duração dos pulsos e o "endpoint" da aplicação, que em seu estudo foi o desenvolvimento de eritema ao invés de sangramento pontual. (Prieto et al.; 2002). Além disto, pode-se enumerar outras diferenças entre os estudos citados que dificultam uma comparação confiável dos resultados, como os filtros utilizados, que no de Hernández-Pérez e lbiett (2002b) foi de 645 nm e os modelos dos aparelhos, que no de HernándezPérez e Ibiett (2002b) e no de Bitter (2000) foi o Vasculight ${ }^{\circledR}$. No estudo de Pietro (2002), em que os resultados foram semelhantes ao do estudo atual, também se utilizou o filtro de 560nm e o modelo de aparelho foi o mesmo (IPL Quantum®) Também, nos estudos citados, exceto no de HernándezPérez e Ibiett (2002b), não há menção quanto à realização da avaliação dos 
casos pré e pós-tratamento de forma cega, o que torna os resultados menos fidedignos.

Civatte (1923) em seu trabalho original descreveu que as fibras elásticas estavam reduzidas e até ausentes na PC. Entretanto, os estudos atuais mostram que há predomínio da elastose, com fibras elásticas agrupadas de modo grosseiro, fragmentadas e aumentadas em número (Duarte, 1996; Bertino, 1997). No presente estudo, observou-se a presença da degeneração basofílica do tecido conjuntivo em todos os casos avaliados.

O fotorejuvenescimento não-ablativo é um método que tem sido bastante estudado atualmente visando a reversão do envelhecimento cutâneo, através da utilização da LIP ou do LASER. O objetivo é criar um dano dérmico sem ablação da epiderme. A reação da derme à agressão se faz pelo aumento da produção de colágeno e reabsorção do material elastótico (Goldberg, Silapunt, 2001). As explicações para a síntese de novo colágeno incluem a absorção da luz pelo sangue, que aumenta a temperatura ao redor dos vasos, transferindo o dano térmico ao tecido adjacente e causando a liberação de mediadores inflamatórios, que induziriam o processo de cicatrização. A energia também estimularia diretamente os fibroblastos a produzirem mais colágeno (Lee, 2003).

Vários estudos que utilizaram diferentes tipos de LASER para o fotorejuvenescimento não-ablativo no tratamento do envelhecimento cutâneo, fizeram avaliação histopatológica e demonstraram síntese de colágeno e melhora da elastose solar em diferentes graus (Menaker et al., 
1999; Goldberg, 2000; Fournier et al., 2001; Goldberg, Silapunt, 2001; Trelles et al., 2001; Lee, 2003).

Em um estudo muito interessante, foram tratados nove pacientes com fotoenvelhecimento, sendo sete com LASER de corante pulsado (LCP) e dois com LIP (não cita o filtro), os quais foram submetidos à biópsia da pele da área periorbital antes e até 6 semanas após o tratamento. Foi realizado estudo imunohistoquímico utilizando anticorpos para procolágeno, colágeno tipo I e III, colagenase, elastina e receptor para hialuronidase. Houve aumento de todos os critérios avaliados com ambos os tratamentos. Os autores concluíram que o tratamento das rugas finas ocorre pela estimulação da produção de proteínas e enzimas da matriz extracelular pelos fibroblastos dérmicos (Zelickson, Kist, 2000).

Considerando-se que na PC ocorre um aumento das fibras elásticas em relação à pele normal, e que no fotorejuvenescimento não-ablativo ocorre reabsorção do material elastótico, foi utilizado no presente estudo um método de medição da densidade das fibras elásticas para quantificar as modificações ocorridas, esperando-se que houvesse diminuição da densidade após o tratamento. Observou-se que não houve diferença com significância estatística na quantidade de fibras elásticas na derme superficial e profunda após o tratamento.

Estes achados estão de acordo com os de Prieto et al. (2002), já citados, que ao tratarem a face de cinco pacientes com protocolo semelhante, nas análises histológicas não observaram diferença na 
quantidade, qualidade ou alterações morfológicas nas fibras colágenas, elásticas e de reticulina.

Os achados deste trabalho também concordaram com os encontrados no estudo de Hernández-Pérez et al (2002a), em que foram tratadas 15 pacientes com estrias brancas da região abdominal com o Vasculight ${ }^{\circledR}$ Plus, também não ocorrendo modificação das fibras elásticas. Observou-se melhora com significado estatístico na espessura da derme e da epiderme. Os autores sugeriram que, considerando-se que não houve modificação do número de fibras elásticas, o aumento da espessura dérmica teria sido resultado do aumento das fibras colágenas, as quais adquiriram um aspecto mais fibrilar e mais corado. Nesse estudo, o filtro mais comumente utilizado foi o de $645 \mathrm{~nm}$. Foram realizadas cinco sessões com intervalo de 2 semanas entre cada sessão, e as biópsias foram coletadas antes da primeira sessão e 2 semanas após a última sessão.

Um fator a ser considerado é se a amostra foi tomada após ter ocorrido a remodelação do colágeno, que é um processo gradual. Sadick (2003) em um artigo sobre fotorejuvenescimento não-ablativo, afirma que os resultados são tardios, sendo as modificações de pigmentação, vasculares e pilossebáceas notadas em 3 a 6 meses, e a redução das rugas após 12 a 18 meses. Menaker (2001) afirma que a remodelação do colágeno continua por pelo menos 12 meses, tempo após o qual se pode avaliar o resultado final de um estudo. Desta forma, há possibilidade de que com o passar do tempo ocorresse maior redução da elastose nos casos deste estudo, o que poderá ser explorado em futuros trabalhos. 
Quanto à avaliação do componente pigmentar nos cortes histológicos corados pelo Fontana Masson, os achados histopatológicos deste estudo podem explicar os resultados clínicos observados, isto é, a resposta inferior do componente pigmentar. Nesta coloração observou-se redução com significância estatística na quantidade de pigmento melânico na epiderme, porém isto não foi observado na derme. Como citado anteriormente, isto pode ter ocorrido em razão do filtro utilizado, que foi o de $560 \mathrm{~nm}$, que teria atuado mais sobre o pigmento superficial. Em estudo que utilizou a LIP para o tratamento de lesões melanocíticas, os autores afirmaram que para pigmentação superficial pode-se usar filtros tão curtos quanto $515 \mathrm{~nm}$ com bons resultados, enquanto que para pigmentação mais profunda necessitase filtros mais longos (Arias, Ferrando, 2001). Desta forma, é possível que com o filtro utilizado neste estudo não tenha havido penetração da luz em quantidade e profundidade suficiente para atingir o pigmento na derme. Uma possibilidade para novos estudos é a utilização de outros filtros que selecionem comprimentos de onda mais longos, os quais poderiam ser usados associados ao filtro de $560 \mathrm{~nm}$, otimizando a atuação nos componentes pigmentar e vascular da PC.

Outra possibilidade é a de que a irradiação, ao atingir a epiderme, tenha provocado incontinência pigmentar por passagem de pigmento da epiderme para a derme, justificando a redução do pigmento na epiderme e a não redução na derme (Dover, 1989).

Apesar do bom resultado clínico observado do componente vascular, a contagem do número de vasos pela marcação imunohistoquímica pelo 
anticorpo anti-CD34 mostrou redução que não teve significância estatística. Este resultado poderia ser explicado uma vez que, os estudos histológicos e de microscopia confocal mostram, após várias etapas pelas quais passa o tecido depois do tratamento de lesões vasculares com LASER, ocorre a neovascularização, que se inicia a partir de 2 semanas e se completa 4 semanas após a exposição à luz (Aghassi et al., 2000). Desta forma, na avaliação pós-tratamento, que foi realizada 4 semanas após a última sessão, poderiam estar sendo contados os vasos neoformados, o que justificaria a não modificação significativa do número de vasos.

Em função disto, procurou-se avaliar se ocorria modificação no calibre dos vasos após o tratamento. Mediu-se a área ocupada pelo lúmen dos vasos e calculou-se a média, não sendo observada redução após o tratamento. Da mesma forma que para a resposta do pigmento melânico, pode-se presumir que a luz teve uma penetração predominantemente mais superficial na derme, não tendo atuado com a intensidade necessária nos vasos localizados mais profundamente. Em estudo que tratou pacientes com manchas vinho do Porto com LASER de corante pulsado de $585 \mathrm{~nm}$, com análise histológica prévia ao tratamento, os pacientes com os vasos de localização mais profunda apresentaram resposta clínica inferior aos pacientes que apresentavam vasos de localização mais superficial (Fiskerstrand et al., 1996). Considerando-se que a faixa de atuação desse LASER situa-se próxima à faixa do filtro utilizado neste estudo, a comparação é útil ao entendimento de que a atuação no componente profundo não é tão satisfatória. 
O presente trabalho demonstrou bons resultados clínicos após a utilização da luz intensa pulsada para o tratamento da poiquilodermia de Civatte, e mostrou que há uma diferença de resposta dos componentes vascular e pigmentar ao tratamento. A conhecimento desta diferença é útil ao se avaliar um paciente antes do tratamento, pois fornece condições de se estimar a possível resposta que será obtida. Também mostrou que o procedimento é seguro, estando associado à baixa incidência de efeitos colaterais, os quais são reversíveis. Desta forma, se constitui em uma boa opção de tratamento para esta afecção com tão escassos recursos disponíveis. 


\section{6- CONCLUSÕES}

1- No tratamento da poiquilodermia de Civatte com luz intensa pulsada utilizando-se o filtro de $560 \mathrm{~nm}$, observou-se clinicamente que o componente vascular respondeu melhor do que o componente pigmentar em $69,3 \%$ dos casos $(p<0,001)$, ambos responderam da mesma forma em $26,7 \%$ dos casos e o componente pigmentar respondeu melhor do que o componente vascular em $4 \%$ dos casos.

2- Os efeitos colaterais observados com a utilização da luz intensa pulsada para o tratamento da poiquilodermia de Civatte foram de eritema (100\% dos pacientes), formação de crostas (93,3\% dos pacientes), edema (66,7\% dos pacientes), ruptura da integridade epidérmica (40\% dos pacientes), púrpura (26,7\% dos pacientes), persistência de áreas lineares não tratadas (20\% dos pacientes) e hiperpigmentação pós-inflamatória (6,7\% dos pacientes), estando de acordo com os descritos na literatura.

3- Não houve diferença estatisticamente significativa da densidade das fibras elásticas da derme superficial e profunda nas amostras pré e póstratamento da poiquilodermia de Civatte com luz intensa pulsada. 
4- Houve redução da quantidade de pigmento melânico na epiderme com significância estatística $(p=0,0446)$ após a utilização da luz intensa pulsada para o tratamento da poiquilodermia de Civatte. Não houve redução na derme.

5- A avaliação do número de vasos e da média da área do lúmem dos vasos na derme superficial e profunda utilizando o anticorpo anti-CD34 não mostrou redução com significância estatística nos pacientes com poiquilodermia de Civatte tratados com luz intensa pulsada. 


\section{6- ANEXOS}

\section{ANEXO A - TERMO DE CONSENTIMENTO \\ HOSPITAL DAS CLIINICAS \\ DA \\ FACULDADE DE MEDICINA DA UNIVERSIDADE DE SÃO PAULO \\ TERMO DE CONSENTIMENTO LIVRE E ESCLARECIDO \\ (Instruções para preenchimento no verso)}

\section{I - DADOS DE IDENTIFICAÇÃO DO SUJEITO DA PESQUISA OU RESPONSÁVEL LEGAL}

1. NOME DO PACIENTE

DOCUMENTO DE IDENTIDADE № : SEXO: $M[$ ] $F[$ ]

DATA NASCIMENTO: ........................

ENDEREÇO № APTO:

BAIRRO: CIDADE

CEP: TELEFONE: DDD

2.RESPONSÁVEL LEGAL

NATUREZA (grau de parentesco, tutor, curador etc.)

DOCUMENTO DE IDENTIDADE SEXO: $M[$ ] $F[$ ] DATA NASCIMENTO.: .................... ENDEREÇO: № APTO:

BAIRRO:

CEP:

\section{II - DADOS SOBRE A PESQUISA CIENTÍFICA}

1.TÍTULO DO PROTOCOLO DE PESQUISA

"Alterações histopatológicas após a aplicação da Luz Intensa Pulsada para o tratamento de pacientes com poiquilodermia de Civatte."

2.PESQUISADOR: Luiz Carlos Cucé CARGO/FUNÇÃO: Professor associado INSCRIÇÃO CONSELHO REGIONAL: 9575 UNIDADE DO HCFMUSP: Departamento de Dermatologia 3.AVALIAÇÃO DO RISCO DA PESQUISA:

\section{SEM RISCO [ ] RISCO MÍNIMO [ X ] RISCO MÉDIO [ ] RISCO BAIXO [ ] RISCO MAIOR [ ]}

(probabilidade de que o indivíduo sofra algum dano como conseqüência imediata ou tardia do estudo)

4.DURAÇÃO DA PESQUISA : 2 anos 


\section{INSTRUÇÕES PARA PREENCHIMENTO}

(Resolução Conselho Nacional de Saúde 196, de 10 outubro 1996)

1.Este termo conterá o registro das informações que o pesquisador fornecerá ao sujeito da pesquisa, em linguagem clara e accessível, evitando-se vocábulos técnicos não compatíveis com o grau de conhecimento do interlocutor.

2.A avaliação do grau de risco deve ser minuciosa, levando em conta qualquer possibilidade de intervenção e de dano à integridade física do sujeito da pesquisa.

3.O formulário poderá ser preenchido em letra de forma legível, datilografia ou meios eletrônicos.

4. Este termo deverá ser elaborado em duas vias, ficando uma via em poder do paciente ou seu representante legal e outra deverá ser juntada ao prontuário do paciente.

5.A via do Termo de Consentimento Pós-Informação submetida à análise da Comissão de Ética para Análise de Projetos de Pesquisa -CAPPesq deverá ser idêntica àquela que será fornecida ao sujeito da pesquisa. 


\section{III - REGISTRO DAS EXPLICAÇÕES DO PESQUISADOR AO PACIENTE OU SEU REPRESENTANTE LEGAL SOBRE A PESQUISA, CONSIGNANDO:}

1. Justificativa e objetivos da pesquisa

A poiquilodermia de Civatte é uma alteração da pele em que ocorre modificação da sua cor e que pode ser vista no pescoço, no colo ou na face. Além da questão estética, alguns pacientes que possuem esta alteração podem sentir coceira ou queimação no local. Um tipo especial da luz chamado LIP vem sendo empregada para o tratamento desta alteração, já sendo utilizada pelos dermatologistas em seus consultórios. Este estudo está sendo realizado para avaliarmos o grau de clareamento e o que acontece na estrutura da pele após o tratamento com um aparelho de LIP chamado Quantum ${ }^{\circledR}$.

2. Procedimentos que serão utilizados e propósitos

Participarão do estudo 16 pacientes que possuam esta alteração na pele do pescoço. A aplicação da luz será feita uma vez por mês durante 5 meses no Hospital das Clínicas. Para evitar prejuízo à visão, serão utilizados óculos de proteção durante as aplicações da luz. Serão realizadas fotografias da região do pescoço antes e após o tratamento. Serão retirados pequenos pedacinhos de pele para estudo (biópsia), antes e após o término das cinco sessões. Para a retirada dos pedacinhos de pele, será feita uma anestesia local e será dado um ponto para diminuir a possibilidade de cicatriz. O ponto será retirado após 1 semana. Após o tratamento, deve-se evitar a exposição ao sol, e durante o dia deve-se estar sempre utilizando bloqueador solar.

3. Desconforto e riscos esperados

A aplicação da luz provoca pouco desconforto, o qual lembra uma sensação de queimação. Esta sensação é mais intensa no momento da aplicação e tende a diminuir, em seguida, progressivamente. Logo após a aplicação a pele fica vermelha e inchada. A pele pode ficar roxa em alguns locais, o que melhora espontaneamente em aproximadamente uma semana. Em alguns casos a pele pode se romper e depois cicatriza. Nestes casos será indicado o uso de um creme de antibiótico. Outra alteração possível é a formação de casquinhas escuras no local. Estas casquinhas não deverão ser arrancadas, espere que caiam naturalmente. O local tratado pode ficar temporariamente mais escuro ou mais claro do que a cor da pele ao redor. Esta alteração da cor tende a desaparecer aos poucos em algumas semanas, e raramente pode demorar meses.

A biópsia é um procedimento seguro, estando raramente associada a complicações como sangramento ou infecção. Habitualmente deixa uma pequena marca ne pele, sendo que a realização do ponto diminui sua percepção.

Uma outra possibilidade seria a não melhora da poiquilodermia após o tratamento. 
4. Benefícios que poderão ser obtidos

Como já mencionado, este tratamento é seguro e já vem sendo utilizado para o tratamento da poiquilodermia e também de outras alterações da pele. A cada sessão deverá ser notado um clareamento progressivo das manchas.

5. Procedimentos alternativos

Existem outros tratamentos que também são ou já foram utilizados para o tratamento da poiquilodermia. A utilização de cremes clareadores é segura, porém tem um efeito muito pequeno. Outros tratamentos já realizados incluem a aplicação de ácidos, aplicação de nitrogênio líquido e a eletrocauterização, todos agressivos e com possibilidade de efeitos colaterais, principalmente a formação de cicatriz. Outras formas de luz, como o LASER, também têm sido utilizadas com bons resultados no tratamento da poiquilodermia.

\section{IV - ESCLARECIMENTOS DADOS PELO PESQUISADOR SOBRE GARANTIAS DO SUJEITO DA PESQUISA:}

1.A qualquer momento, o(a) senhor(a) poderá receber todas as informações que quiser sobre o estudo, para esclarecimento de quaisquer dúvidas que possam surgir.

2.A qualquer momento, o(a) senhor(a) tem liberdade para deixar de participar do estudo, sem que isto traga qualquer prejuízo ao seu acompanhamento.

3.Em nenhum momento da pesquisa serão divulgados seu nome ou quaisquer informações pessoais, estando assegurada sua privacidade.

4.Em caso de algum prejuízo à sua saúde decorrente do estudo, o(a) senhor(a) receberá acompanhamento no Hospital das Clínicas da FMUSP.

5.Em caso de eventuais danos à sua saúde decorrentes do estudo, será avaliada a possibilidade de indenização.

\section{V - INFORMAÇÕES DE NOMES, ENDEREÇOS E TELEFONES DOS RESPONSẢVEIS PELO ACOMPANHAMENTO DA PESQUISA, PARA CONTATO EM CASO DE INTERCORRÊNCIAS CLÍNICAS E REAÇÕES ADVERSAS.}

Dra. Tatiana Basso Biasi

Consultório: Av 11 do julho, 88 / Vila Clementino / CEP 04041-000 / Tel (11) 55748599

Celular (11) 93774313 


\section{VI - CONSENTIMENTO PÓS-ESCLARECIDO}

Declaro que, após convenientemente esclarecido pelo pesquisador e ter entendido o que me foi explicado, consinto em participar do presente Protocolo de Pesquisa

São Paulo,

de

de 


\section{ANEXO B - ENTREVISTA}

Nome:

Endereço: Rua / Av

Bairro

Telefones para contato:

Naturalidade: Procedência:

Profissão:

Sexo: ( )M ( )F Data de nascimento:

Fototipo ( )I ( )II ( )III ( )IV ( )V

Tempo de evolução:

Casos na família (especificar quem):

Localização: ( )Pescoço ( ) Colo ( ) Face

Compomentes: ( ) Pigmentação acastanhada ( ) Eritema ( )Telangiectasias ( )Atrofia

Sintomas:

Exposição solar (quanto e há quanto tempo):

Uso de filtro solar:

Uso de cosméticos/perfumes na região cervical:

Tratamentos anteriores:

Outras doenças de pele / geral:

Uso de medicações:

Menopausa: História de quelóide: 


\section{ANEXO C - ORIENTAÇÕES PARA A ANÁLISE DAS FOTOGRAFIAS:}

- Os pacientes do estudo eram portadores de poiquilodermia de Civatte na região cervical, sendo submetidos ao tratamento com luz intensa $p$ ulsada.

- Todos os casos foram fotografados em 3 posições: cervical anterior, cervical direita e esquerda.

- Os pacientes foram tratados na região cervical, observar esta área, e não o colo ou a face.

- As fotos pré-tratamento estarão sempre no lado esquerdo do monitor e as fotos pós-tratamento no lado direito do monitor.

- Analisar de forma separada o componente vascular, tendo com parâmetros clínicos a presença de telangiectasias e o eritema difuso e o componente pigmentar, tendo com parâmetro clínico a pigmentação acastanhada.

- Analizar as fotos quanto ao clareamento, classificando com um "X" em "pior", "não alterado", "pouco melhor (<50\%)" ou "muito melhor (>50\%)"

"pior" - se você achou que na área em questão houve acentuação do componente avaliado.

"não alterado" - se você achou que na área em questão não houve modificação do componente avaliado.

"pouco melhor ( $<50 \%)$ " - se você achou que na área em questão houve melhora inferior a $50 \%$ no componente avaliado

"muito melhor ( $>50 \%$ )" - se você achou que na área em questão houve melhora superior a $50 \%$ no componente avaliado.

- Quando um dos componentes não estiver distinguível em relação ao outro, colocar "não destacado".

- Se você achou que houve melhora em apenas um lado ou uma área, prevalece, na avaliação global, o lado ou a área que melhorou, pois indica que o tratamento é capaz de proporcionar melhora. Assim, classifique como melhor. Da mesma forma, se houver pouca melhora em uma área e muita melhora na outra, classificar como "muito melhor".

- Obrigada pela participação.

Tatiana Basso Biasi 


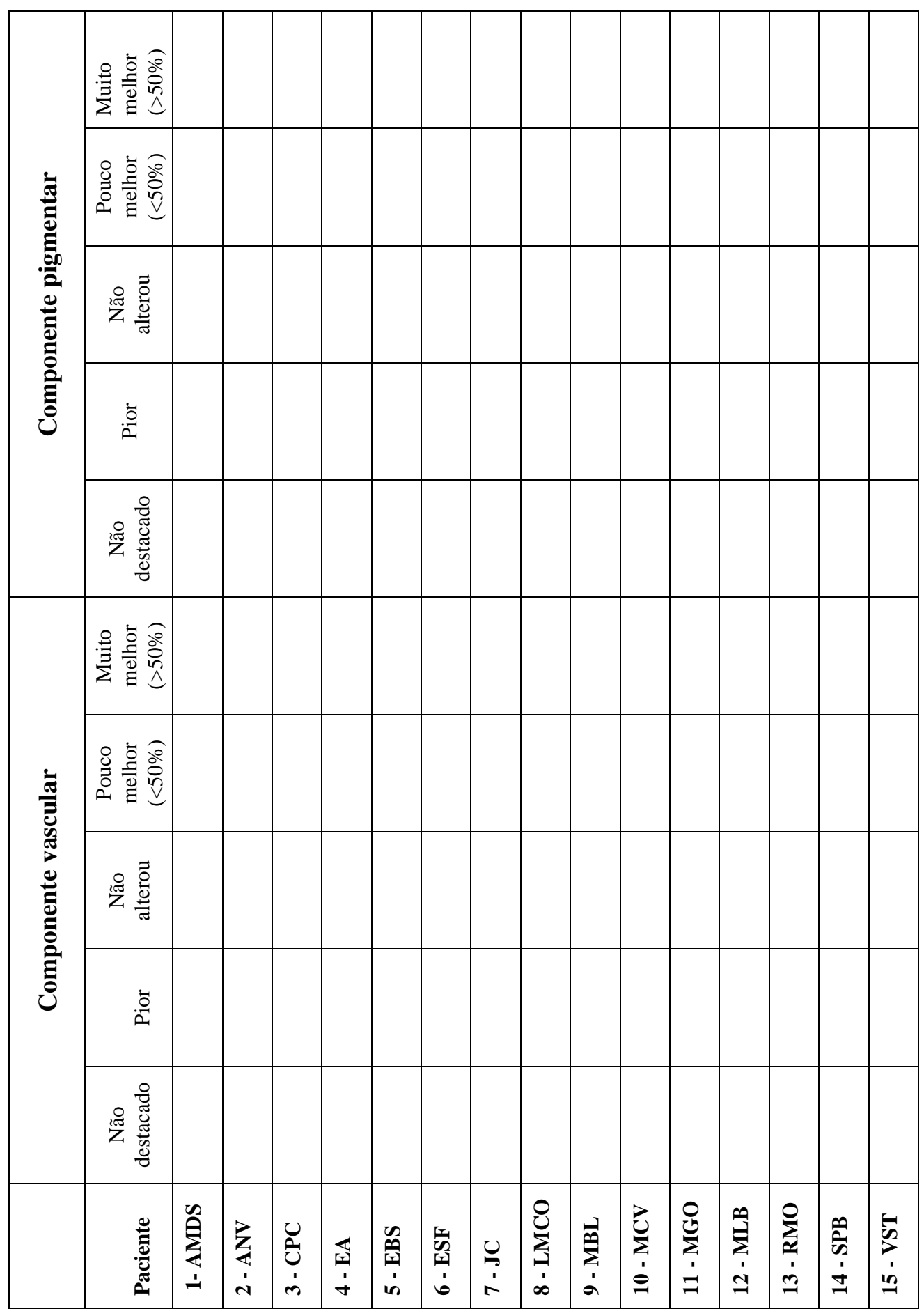




\section{ANEXO D - TABELAS ESTATÍSTICAS}

Tabela 5 - Escores de resposta clínica dos componentes pigmentar e vascular das lesões de poiquilodermia de Civatte tratadas com luz intensa pulsada, avaliados por cinco observadores a partir das fotografias de 15 pacientes

\begin{tabular}{lcccccc}
\hline \multirow{2}{*}{$\begin{array}{l}\text { COMPONENTE } \\
\text { PIGMENTAR }\end{array}$} & $\begin{array}{c}\text { Não } \\
\text { destacado }\end{array}$ & Pior & $\begin{array}{c}\text { Não } \\
\text { alterado }\end{array}$ & $\begin{array}{c}\text { Pouco } \\
\text { melhor }\end{array}$ & $\begin{array}{c}\text { Muito } \\
\text { melhor }\end{array}$ & $\begin{array}{c}\text { TOTAL DE } \\
\text { CASOS }\end{array}$ \\
\hline Não destacado & 0 & 0 & 3 & 7 & 13 & 23 \\
Pior & 0 & 1 & 0 & 3 & 0 & 4 \\
Não alterado & 1 & 0 & 2 & 6 & 6 & 15 \\
Pouco melhor & 1 & 0 & 0 & 4 & 14 & 19 \\
Muito melhor & 0 & 0 & 0 & 1 & 13 & 14 \\
\hline TOTAL DE CASOS & 2 & 1 & 5 & 21 & 46 & 75 \\
\hline
\end{tabular}

Teste Kappa

$\mathrm{Kw}=0,09$

$\mathrm{Z}$ calc $=1,51(\mathrm{NS})$

$Z$ crit $=1,96$

Teste de McNemar

$X^{2}$ calc $=43,66^{*}(p<0,001)$

$X^{2}$ crit $=3,84$

Concordância diagonal = 26,7\% (CONCORDÂNCIA ENTRE OS DOIS COMPONENTES) Acima da diagonal $=69,3 \%$ (VASCULAR TEM EVOLUÇÃO MELHOR QUE PIGMENTAR) Abaixo da diagonal $=4 \%$ (PIGMENTAR TEM EVOLUÇẨO MELHOR QUE VASCULAR) 
Tabela 6 - Indivíduos portadores de poiquilodermia de Civatte submetidos ao tratamento com luz intensa pulsada, segundo a presença de hiperceratose na coloração por hematoxilina e eosina, nos períodos pré e pós-tratamento

\begin{tabular}{lcccc} 
& \multicolumn{2}{c}{ PÓS-TRATAMENTO } & \\
\cline { 2 - 3 } PRÉ-TRATAMENTO & Presença & Ausência & TOTAL DE CASOS \\
\hline Presença & 9 & 3 & 12 \\
Ausência & 2 & 1 & 3 \\
\hline TOTAL DE CASOS & 11 & 4 & 15 \\
\hline
\end{tabular}

Teste Kappa

$\mathrm{Kw}=0,07$

$\mathrm{Z}$ calc $=0,30(\mathrm{NS})$

$Z$ crit $=1,96$

Teste de McNemar

$\mathrm{X}^{2}$ calc $=0,00(\mathrm{NS})$

$\mathrm{X}^{2}$ crit $=3,84$

Concordância diagonal $=66,7 \%$

Acima da diagonal $=20 \%$ (MELHORADOS)

Abaixo da diagonal $=13,3 \%$ (PIORADOS)

Tabela 7 - Indivíduos portadores de poiquilodermia de Civatte submetidos ao tratamento com luz intensa pulsada, segundo a presença de retificação da epiderme na coloração por hematoxilina e eosina, nos períodos pré e pós-tratamento

\begin{tabular}{lcccc}
\hline & \multicolumn{2}{c}{ PÓS-TRATAMENTO } & \\
\cline { 2 - 3 } PRÉ-TRATAMENTO & Presença & Ausência & TOTAL DE CASOS \\
\hline Presença & 5 & 1 & 6 \\
Ausência & 3 & 6 & 9 \\
\hline TOTAL DE CASOS & 8 & 7 & 15 \\
\hline
\end{tabular}

Teste Kappa

$\mathrm{Kw}=0,47$

$\mathrm{Z}$ calc $=1,90(\mathrm{NS})$

$Z$ crit $=1,96$

Teste de McNemar

$\mathrm{X}^{2}$ calc $=2,25(\mathrm{NS})$

$\mathrm{X}^{2}$ crit $=3,84$

Concordância diagonal $=73,3 \%$

Acima da diagonal $=6,7 \%$ (MELHORADOS)

Abaixo da diagonal $=20 \%$ (PIORADOS) 
Tabela 8 - Indivíduos portadores de poiquilodermia de Civatte submetidos ao tratamento com luz intensa pulsada, segundo a presença de degeneração hidrópica dos queratinócitos basais na coloração por hematoxilina e eosina, nos períodos pré e pós-tratamento

\begin{tabular}{lcccc}
\hline & \multicolumn{2}{c}{ PÓS-TRATAMENTO } & \\
\cline { 2 - 3 } PRÉ-TRATAMENTO & Presença & Ausência & TOTAL DE CASOS \\
\hline Presença & 1 & 1 & 2 \\
Ausência & 4 & 9 & 13 \\
\hline TOTAL DE CASOS & 5 & 10 & 15 \\
\hline
\end{tabular}

Teste Kappa

$\mathrm{Kw}=0,19$

$\mathrm{Z}$ calc $=0,54(\mathrm{NS})$

$\mathrm{Z}$ crit $=1,96$

Teste de McNemar

$\mathrm{X}^{2}$ calc $=3,20$ (NS)

$X^{2}$ crit $=3,84$

Concordância diagonal $=66,7 \%$

Acima da diagonal $=6,7 \%$ (MELHORADOS)

Abaixo da diagonal $=26,7 \%$ (PIORADOS)

Tabela 9 - Indivíduos portadores de poiquilodermia de Civatte submetidos ao tratamento com luz intensa pulsada, segundo a presença de zona grenz na coloração por hematoxilina e eosina, nos períodos pré e pós-tratamento

\begin{tabular}{lcccc}
\hline & \multicolumn{2}{c}{ PÓS-TRATAMENTO } & \\
\cline { 2 - 3 } PRÉ-TRATAMENTO & Presença & Ausência & TOTAL DE CASOS \\
\hline Presença & 3 & 2 & 5 \\
Ausência & 1 & 9 & 10 \\
\hline TOTAL DE CASOS & 4 & 11 & 15 \\
\hline
\end{tabular}

Teste Kappa

$\mathrm{Kw}=0,53$

$Z$ calc $=2,06^{*}(p<0,05)$

$Z$ crit $=1,96$

Teste de McNemar

$\mathrm{X}^{2}$ calc $=0,00(\mathrm{NS})$

$\mathrm{X}^{2}$ crit $=3,84$

Concordância diagonal $=80 \%$

Acima da diagonal $=13,3 \%$ (PIORADOS)

Abaixo da diagonal $=6,7 \%$ (MELHORADOS) 
Tabela 10 - Indivíduos portadores de poiquilodermia de Civatte submetidos ao tratamento com luz intensa pulsada, segundo a presença de proliferação vascular na coloração por hematoxilina e eosina, nos períodos pré e póstratamento

\begin{tabular}{cccc}
\hline & \multicolumn{2}{c}{ PÓS-TRATAMENTO } & \\
\cline { 2 - 3 } PRÉ-TRATAMENTO & Presença & Ausência & TOTAL DE CASOS \\
\hline Presença & 8 & 3 & 11 \\
Ausência & 3 & 1 & 4 \\
\hline TOTAL DE CASOS & 11 & 4 & 15 \\
\hline
\end{tabular}

Teste Kappa

$\mathrm{Kw}=0,02$

$\mathrm{Z}$ calc $=0,09(\mathrm{NS})$

$\mathrm{Z}$ crit $=1,96$

Teste de McNemar

$\mathrm{X}^{2}$ calc $=0,17(\mathrm{NS})$

$\mathrm{X}^{2}$ crit $=3,84$

Concordância diagonal $=60 \%$

Acima da diagonal $=20 \%$ (MELHORADOS)

Abaixo da diagonal $=20 \%$ (PIORADOS)

Tabela 11 - Indivíduos portadores de poiquilodermia de Civatte submetidos ao tratamento com luz intensa pulsada, segundo a presença de hiperplasia das glândulas sebáceas na coloração por hematoxilina e eosina, nos períodos pré e pós-tratamento

\begin{tabular}{lcccc}
\hline & \multicolumn{2}{c}{ PÓS-TRATAMENTO } & \\
\cline { 2 - 3 } PRÉ-TRATAMENTO & Presença & Ausência & TOTAL DE CASOS \\
\hline Presença & 0 & 1 & 1 \\
Ausência & 1 & 13 & 14 \\
\hline TOTAL DE CASOS & 1 & 14 & 15 \\
\hline
\end{tabular}

Teste Kappa

$\mathrm{Kw}=0,72$

$\mathrm{Z}$ calc $=0,28(\mathrm{NS})$

$Z$ crit $=1,96$

Teste de McNemar

$\mathrm{X}^{2}$ calc $=0,50(\mathrm{NS})$

$\mathrm{X}^{2}$ crit $=3,84$

Concordância diagonal $=86,7 \%$

Acima da diagonal $=6,7 \%$ (MELHORADOS)

Abaixo da diagonal $=6,7 \%$ (PIORADOS) 
Tabela 12 - Indivíduos portadores de poiquilodermia de Civatte submetidos ao tratamento com luz intensa pulsada, segundo a intensidade da degeneração basofílica do tecido conjuntivo na coloração por hematoxilina e eosina, nos períodos pré e pós-tratamento

\begin{tabular}{|c|c|c|c|c|}
\hline \multirow[b]{2}{*}{ PRÉ-TRATAMENTO } & \multicolumn{3}{|c|}{ PÓS-TRATAMENTO } & \multirow[b]{2}{*}{$\begin{array}{l}\text { TOTAL DE } \\
\text { CASOS }\end{array}$} \\
\hline & Leve & Moderado & Intenso & \\
\hline Leve & 6 & 2 & 0 & 8 \\
\hline Moderado & 4 & 2 & 0 & 6 \\
\hline Intenso & 0 & 1 & 0 & 1 \\
\hline TOTAL DE CASOS & 10 & 5 & 0 & 15 \\
\hline
\end{tabular}

Teste Kappa

$\mathrm{Kw}=0,16$

$\mathrm{Z}$ calc $=0,38(\mathrm{NS})$

$Z$ crit $=1,96$

Teste de McNemar

$\mathrm{X}^{2}$ calc $=1,29$ (NS)

$X^{2}$ crit $=3,84$

Concordância diagonal $=53,3 \%$

Acima da diagonal $=13,3 \%$ (PIORADOS)

Abaixo da diagonal $=33,3 \%$ (MELHORADOS)

Tabela 13 - Indivíduos portadores de poiquilodermia de Civatte submetidos ao tratamento com luz intensa pulsada, segundo a intensidade do infiltrado inflamatório na coloração por hematoxilina e eosina, nos períodos pré e pós-tratamento

\begin{tabular}{lcccc}
\hline PRÉ-TRATAMENTO & \multicolumn{3}{c}{ PÓS-TRATAMENTO } & \\
\cline { 2 - 4 } & Leve & Moderado & Intenso & TOTAL DE \\
Leve & 13 & 1 & 0 & 14 \\
Moderado & 1 & 0 & 0 & 1 \\
Intenso & 0 & 0 & 0 & 0 \\
\hline TOTAL DE CASOS & 14 & 1 & 0 & 15 \\
\hline
\end{tabular}

Teste Kappa

$\mathrm{Kw}=0,72$

$\mathrm{Z}$ calc $=0,28(\mathrm{NS})$

$Z$ crit $=1,96$

Teste de McNemar

$\mathrm{X}^{2}$ calc $=0,00$ (NS)

$X^{2}$ crit $=3,84$

Concordância diagonal $=86,7 \%$

Acima da diagonal $=6,7 \%$ (PIORADOS)

Abaixo da diagonal $=6,7 \%$ (MELHORADOS) 
Tabela 14 - Indivíduos portadores de poiquilodermia de Civatte submetidos ao tratamento com luz intensa pulsada, segundo os valores da área de fibras elásticas coradas pelo Weigert com oxidação, em relação à área total medida, na derme superficial e profunda, nos períodos pré e pós-tratamento. Valores das diferenças percentuais $(\Delta \%)$ calculados a partir dos dois períodos

\begin{tabular}{ccccccc}
\hline & \multicolumn{3}{c}{ SUPERFICIAL } & \multicolumn{3}{c}{ PROFUNDO } \\
PACIENTE & Pré & Pós & $\Delta \%$ & Pré & Pós & $\Delta \%$ \\
\hline 1 & 6,69 & 7,53 & 12,56 & 9,83 & 11,19 & 13,84 \\
2 & 7,51 & 5,93 & $(21,04)$ & 16,85 & 10,46 & $(37,92)$ \\
\hline 3 & 8,78 & 5,60 & $(36,21)$ & 9,30 & 13,43 & 44,41 \\
4 & 9,81 & 5,01 & $(48,93)$ & 10,87 & 10,02 & $(7,82)$ \\
\hline 5 & 7,08 & 5,43 & $(23,31)$ & 11,92 & 9,18 & $(22,99)$ \\
6 & 5,99 & 5,11 & $(14,69)$ & 8,45 & 11,58 & 37,04 \\
7 & 4,37 & 2,93 & $(32,95)$ & 14,51 & 6,43 & $(55,69)$ \\
\hline 8 & 3,06 & 6,14 & 100,65 & 11,66 & 19,69 & 68,87 \\
\hline 9 & 13,5 & 10,63 & $(21,26)$ & 12,10 & 17,79 & 47,02 \\
10 & 4,24 & 12,98 & 206,13 & 10,91 & 18,78 & 72,14 \\
11 & 7,64 & 2,7 & $(64,66)$ & 30,80 & 26,31 & $(14,58)$ \\
\hline 12 & 4,51 & 8,17 & 81,15 & 12,92 & 9,49 & $(26,55)$ \\
\hline 13 & 23,07 & 7,60 & $(67,05)$ & 19,17 & 11,87 & $(38,08)$ \\
\hline 14 & 4,40 & 2,78 & $(36,82)$ & 14,15 & 5,35 & $(62,19)$ \\
\hline 15 & 3,31 & 0,90 & $(72,81)$ & 9,28 & 2,03 & $(78,13)$ \\
\hline MÉDIA & 7,60 & 5,96 & $(2,62)$ & 13,51 & 12,24 & $(4,04)$ \\
MEDIANA & 6,69 & 5,60 & $(23,31)$ & 11,92 & 11,19 & $(14,58)$ \\
\hline
\end{tabular}

Teste de Wilcoxon (Pré X Pós)

Superficial

$\mathrm{Z}$ calc $=1,42(\mathrm{NS})$

$Z$ crit $=1,64$

Profundo

$\overline{Z \text { calc }=0,85(\mathrm{NS})}$

$Z$ crit $=1,64$

Superficial $X$ Profundo (Para valores de $\Delta \%$ )

$\mathrm{Z}$ calc $=0,28(\mathrm{NS})$

$Z$ crit $=1,64$ 
Tabela 15 - Indivíduos portadores de poiquilodermia de Civatte submetidos ao tratamento com luz intensa pulsada, segundo os valores da área com pigmento melânico coradas pelo Fontana Masson em relação à área total medida, na epiderme e derme justa-epidérmica, nos períodos pré e pós-tratamento. Valores das diferenças percentuais $(\Delta \%)$ calculados a partir dos dois períodos

\begin{tabular}{|c|c|c|c|c|c|c|}
\hline \multirow[b]{2}{*}{ PACIENTE } & \multicolumn{3}{|c|}{ EPIDERME } & \multicolumn{3}{|c|}{ DERME } \\
\hline & Pré & Pós & $\Delta \%$ & Pré & Pós & $\Delta \%$ \\
\hline 1 & 7,87 & 6,88 & $(12,58)$ & 0,13 & 0,18 & 38,46 \\
\hline 2 & 7,64 & 3,95 & $(48,37)$ & 0,36 & 0,17 & $(52,78)$ \\
\hline 3 & 5,57 & 5,69 & 2,15 & 0,26 & 0,20 & $(23,08)$ \\
\hline 4 & 6,89 & 3,56 & $(48,33)$ & 0,07 & 0,14 & 100 \\
\hline 5 & 9,57 & 4,16 & $(56,53)$ & 0,38 & 0,18 & $(52,63)$ \\
\hline 6 & 3,01 & 3,78 & 25,58 & 0,20 & 0,38 & 90 \\
\hline 7 & 7,72 & 6,31 & $(18,26)$ & 0,10 & 0,16 & 60 \\
\hline 8 & 8,96 & 7,20 & $(19,64)$ & 0,17 & 0,05 & $(70,59)$ \\
\hline 9 & 8,99 & 4,09 & $(54,51)$ & 0,37 & 0,14 & $(62,16)$ \\
\hline 10 & 7,27 & 8,66 & 19,12 & 0,13 & 0,30 & 130,77 \\
\hline 11 & 12,28 & 7,07 & $(42,43)$ & 0,10 & 0,08 & (20) \\
\hline 12 & 2,40 & 19,43 & 709,58 & 0,33 & 0,54 & 63,64 \\
\hline 13 & 5,61 & 6,79 & 21,03 & 0,32 & 0,37 & 15,62 \\
\hline 14 & 2,95 & 2,82 & $(4,41)$ & 0,12 & 0,05 & $(58,33)$ \\
\hline 15 & 7,84 & 4,85 & $(38,14)$ & 0,08 & 0,36 & 350 \\
\hline MÉDIA & 6,97 & 6,35 & 28,95 & 0,21 & 0,22 & 33,93 \\
\hline MEDIANA & 7,64 & 5,69 & $(18,26)$ & 0,17 & 0,18 & 15,62 \\
\hline
\end{tabular}

Teste de Wilcoxon (Pré X Pós)

Epiderme

$Z$ calc $=1,70 *(p=0,0446)$

$Z$ crit $=1,64$

Derme

$\overline{Z \text { calc }}=0,23(\mathrm{NS})$

$Z$ crit $=1,64$

Epiderme $X$ Derme (Para valores de $\Delta \%$ )

$\mathrm{Z}$ calc $=0,80$ (NS)

$Z$ crit $=1,64$ 
Tabela 16 - Indivíduos portadores de poiquilodermia de Civatte submetidos ao tratamento com luz intensa pulsada, segundo os valores da área com pigmento melânico coradas pelo Fontana Masson em relação à área total medida, na epiderme e derme justa-epidérmica, nos períodos pré e pós-tratamento, excluídos dois casos com valores discrepantes. Valores das diferenças percentuais $(\Delta \%)$ calculados a partir dos dois períodos

\begin{tabular}{|c|c|c|c|c|c|c|}
\hline \multirow[b]{2}{*}{ PACIENTE } & \multicolumn{3}{|c|}{ EPIDERME } & \multicolumn{3}{|c|}{ DERME } \\
\hline & Pré & Pós & $\Delta \%$ & Pré & Pós & $\Delta \%$ \\
\hline 1 & 7,87 & 6,88 & $(12,58)$ & 0,13 & 0,18 & 38,46 \\
\hline 2 & 7,64 & 3,95 & $(48,37)$ & 0,36 & 0,17 & $(52,78)$ \\
\hline 3 & 5,57 & 5,69 & 2,15 & 0,26 & 0,20 & $(23,08)$ \\
\hline 4 & 6,89 & 3,56 & $(48,33)$ & 0,07 & 0,14 & 100 \\
\hline 5 & 9,57 & 4,16 & $(56,53)$ & 0,38 & 0,18 & $(52,63)$ \\
\hline 6 & 3,01 & 3,78 & 25,58 & 0,20 & 0,38 & 90 \\
\hline 7 & 7,72 & 6,31 & $(18,26)$ & 0,10 & 0,16 & 60 \\
\hline 8 & 8,96 & 7,20 & $(19,64)$ & 0,17 & 0,05 & $(70,59)$ \\
\hline 9 & 8,99 & 4,09 & $(54,51)$ & 0,37 & 0,14 & $(62,16)$ \\
\hline 10 & 7,27 & 8,66 & 19,12 & 0,13 & 0,30 & 130,77 \\
\hline 11 & 12,28 & 7,07 & $(42,43)$ & 0,10 & 0,08 & (20) \\
\hline 12 & 5,61 & 6,79 & 21,03 & 0,32 & 0,37 & 15,62 \\
\hline 13 & 2,95 & 2,82 & $(4,41)$ & 0,12 & 0,05 & $(58,33)$ \\
\hline $\begin{array}{c}\text { MÉDIA } \\
\text { MEDIANA }\end{array}$ & $\begin{array}{l}7,26 \\
7,64\end{array}$ & $\begin{array}{l}5,46 \\
5,69\end{array}$ & $\begin{array}{l}(18,23) \\
(18,00)\end{array}$ & $\begin{array}{l}0,21 \\
0,17\end{array}$ & $\begin{array}{l}0,18 \\
0,17\end{array}$ & $\begin{array}{c}7,33 \\
(20,00)\end{array}$ \\
\hline
\end{tabular}

Teste de Wilcoxon (Pré X Pós)

\section{Epiderme}

$\mathrm{Z}$ calc $=2,13^{*}(p=0,033)$

$Z$ crit $=1,64$

$\underline{\text { Derme }}$

$\overline{\mathrm{Z} \text { calc }}=0,73$ (NS)

$Z$ crit $=1,64$

Epiderme X Derme (Para valores de $\Delta \%$ )

$Z$ calc $=1,01(\mathrm{NS})$

$Z$ crit $=1,64$ 
Tabela 17 - Indivíduos portadores de poiquilodermia de Civatte submetidos ao tratamento com luz intensa pulsada, segundo os valores do número de vasos marcados pelo anti-CD34 na derme superficial e profunda, nos períodos pré e póstratamento. Valores das diferenças percentuais $(\Delta \%)$ calculados a partir dos dois períodos

\begin{tabular}{ccccccc}
\hline & \multicolumn{3}{c}{ SUPERFICIAL } & \multicolumn{3}{c}{ PROFUNDO } \\
PACIENTE & Pré & Pós & $\Delta \%$ & Pré & Pós & $\Delta \%$ \\
\hline 1 & 0,5 & 1,0 & 100 & 0,4 & 0,6 & 50 \\
2 & 0,4 & 1,8 & 350 & 0 & 0,4 & - \\
3 & 0,6 & 1,2 & 100 & 0,4 & 0 & $(100)$ \\
4 & 0,4 & 0,6 & 50 & 0 & 0 & 0 \\
5 & 1,0 & 0,4 & $(60)$ & 0,4 & 0,2 & $(50)$ \\
6 & 2,2 & 1,2 & $(45,45)$ & 0,8 & 0,2 & $(75)$ \\
\hline 7 & 0,6 & 0,6 & 0 & 0 & 0,2 & - \\
8 & 1,8 & 1,2 & $(33,33)$ & 0,6 & 0,6 & 0 \\
\hline 9 & 2,2 & 1,0 & $(54,55)$ & 0,4 & 0,4 & 0 \\
10 & 1,8 & 1,4 & $(22,22)$ & 0,4 & 0,6 & 50 \\
11 & 2,6 & 2,4 & $(7,69)$ & 0,8 & 0,8 & 0 \\
12 & 1,4 & 1,6 & 14,29 & 0,4 & 0,2 & $(50)$ \\
\hline 13 & 0,8 & 1,0 & 25 & 0,4 & 0 & $(100)$ \\
14 & 0,8 & 1,0 & 25 & 0,4 & 0,2 & $(50)$ \\
\hline 15 & 1,4 & 1,6 & 14,29 & 0,4 & 0,6 & 50 \\
\hline MÉDIA & 1,23 & 1,20 & 8,10 & 0,39 & 0,33 & $(21,15)$ \\
MEDIANA & 1,00 & 1,20 & 14,29 & 0,40 & 0,20 & 0 \\
\hline
\end{tabular}

Teste de Wilcoxon (Pré X Pós)

Superficial

$Z$ calc $=0,19$ (NS)

$Z$ crit $=1,64$

Profundo

$\mathrm{Z}$ calc $=0,73(\mathrm{NS})$

$Z$ crit $=1,64$

Superficial X Profundo (Para valores de $\Delta \%$ )

$\mathrm{Z}$ calc $=0,46(\mathrm{NS})$

$Z$ crit $=1,64$ 
Tabela 18 - Indivíduos portadores de poiquilodermia de Civatte submetidos ao tratamento com luz intensa pulsada, segundo os valores da média da área do lúmen dos vasos marcados pelo anti-CD34 na derme superficial e profunda, nos períodos pré e pós-tratamento. Valores das diferenças percentuais $(\Delta \%)$ calculados a partir dos dois períodos

\begin{tabular}{ccccccc}
\hline & \multicolumn{3}{c}{ SUPERFICIAL } & \multicolumn{3}{c}{ PROFUNDO } \\
PACIENTE & Pré $\left(\mu^{2}\right)$ & Pós $\left(\mu^{2}\right)$ & $\Delta \%$ & Pré $\left(\mu^{2}\right)$ & Pós $\left(\mu^{2}\right)$ & $\Delta \%$ \\
\hline 1 & 174,70 & 390,88 & ${ }^{(1)} 123,74$ & 0 & 255,51 & - \\
2 & 230,61 & 116,07 & ${ }^{(1)}(49,69)$ & 0 & 1526,43 & - \\
3 & 437,05 & 288,70 & ${ }^{(1)}(33,94)$ & 0 & 492,50 & - \\
4 & 182,59 & 569,75 & ${ }^{(1)} 212,04$ & 0 & 1170,12 & - \\
\hline 5 & 413,71 & 70,16 & ${ }^{(1)}(83,04)$ & 0 & 652,11 & - \\
6 & 613,78 & 515,27 & $(16,05)$ & 184,70 & 0 & $(100)$ \\
\hline 7 & 553,70 & 341,91 & $(38,25)$ & 2173,08 & 470,75 & $(78,33)$ \\
\hline 8 & 265,86 & 2283,09 & 758,76 & 2334,74 & 4614,48 & 97,64 \\
\hline 9 & 2330,15 & 1335,07 & $(42,70)$ & 472,58 & 2877,37 & 508,86 \\
10 & 677,33 & 681,66 & 0,64 & 1776,61 & 1111,09 & $(37,46)$ \\
\hline 11 & 1532,52 & 1207,74 & $(21,19)$ & 2591,87 & 5669,24 & 118,73 \\
12 & 399,47 & 1255,02 & 214,17 & 274,74 & 1298,64 & 4012,48 \\
\hline 13 & 688,96 & 1102,18 & 59,98 & 362,49 & 210,49 & $(41,93)$ \\
\hline 14 & 192,16 & 379,56 & 97,52 & 590,27 & 610,51 & 3,43 \\
\hline 15 & 273,99 & 938,02 & 242,36 & 896,41 & 1679,39 & 87,35 \\
\hline MÉDIA & 597,77 & 765,01 & 125,52 & 777,17 & 1509,24 & 93,10 \\
MEDIANA & 413,71 & 569,75 & 30,31 & 362,49 & 1111,09 & 45,39 \\
\hline
\end{tabular}

(1) Valores excluídos no cálculo da média e mediana para fim de comparação com o $\Delta \%$ do profundo.

Teste de Wilcoxon (Pré X Pós)

Superficial

$Z$ calc $=0,80$ (NS)

$Z$ crit $=1,64$

Profundo

Z calc $=2,04^{*}(p<0,0207)$

$Z$ crit $=1,64$

Superficial X Profundo (Para valores de $\Delta \%$ )

$Z$ calc $=0,42(\mathrm{NS})$

$Z$ crit $=1,64$ 


\section{7- REFERÊNCIAS BIBLIOGRÁFICAS}

Aghassi D, Anderson RR, González S. Time-sequence histologic imaging of laser-treated cherry angiomas with in vivo confocal microscopy. J Am Acad Dermatol. 2000;43:37-41.

Anderson RR. Laser-tissue interactions. In: Goldman MP, Fitzpatrick RE. Cutaneous laser surgery - the art of selective photothermolysis. Boston: Mosby; 1994. p.1-18.

Anderson RR, Parrish JÁ. Selective photothermolysis: precise microsurgery by selective absorption of pulsed irradiation. Science. 1983;220:524-7.

Arias GAM, Ferrando J. Intense pulsed light for melanocytic lesions. Dermatol Surg. 2001;27:397-400.

Azulay RD, Abulafia LA, Azulay DR. Uma nova classificação das fotodermatoses. Med Cut I L A. 1989;17:22-7.

Batta K, Hindson C, Cotterill JA, Foulds IS. Treatment of poikiloderma of Civatte with the potassium titanyl phosphate (KTP) laser. $\mathrm{Br} J$ Dermatol. $1999 ; 140: 1169-70$. 
Bertino MCM. Estudo das fibras elásticas na poiquilodermia de Civatte [dissertação]. São Paulo: Faculdade de Medicina, Universidade de São Paulo; 1997

Bhawan J, Gonzalez-Serva A, Nehal K, Labadie R, Lufrano L, Thorne G, Gilchrest BA. Effects of tretinoin on photodamaged skin. Arch Dermatol. 1991;127: 666-72.

Bitter $\mathrm{PH}$. Noninvasive rejuvenation of photodamaged skin using serial, full-face intense pulsed light treatments. Dermatol Surg. 2000;26:835-43.

Bleehen SS. Disorders of skin colour. In: Champion RH, Burton JL, Burns DA, Breathnach SM; editors. Rook/ Wilkinson/ Ebling: textbook of dermatology. 6th ed. London: Blackwell Science; 1988. p.1753-815.

Burton JL, Lovell CR. Disorders of connective tissue. In: Champion RH, Burton JL, Burns DA, Breathnach SM; editors. Rook/Wilkinson/Ebling: textbook of dermatology. 6th ed. London: Blackwell Science; 1998. p.2003-72.

Butterworth T, Johnson WC. Juxta-clavicular beaded lines. Arch Dermatol. $1974 ; 110: 891-3$.

Calderone DC, Fenske NA. The clinical spectrum of actinic elastosis. J Am Acad Dermatol. 1995;32:1016-24. 
Civatte A. Poikilodermie réticulée pigmentaire du visage et du cou. Ann Dermatol Syphilol. 1923;4:605-20.

Clark RE, Jimenez-Acosta F. Poikiloderma of Civatte. Resolution after treatment with the pulsed dye laser. NC Med J. 1994;55:234-5.

Cota-Pereira G, Guerra Rodrigo F, Bittencourt-Sampaio S. Oxytalan, elaunin, and elastic fibers in the human skin. J Invest Dermatol. 1976;66:143-8.

Cymbalista NC. Hipercromia cutânea idiopática da região orbital: avaliação clínica, histopatológica e imunohistoquímica antes e após tratamento com luz pulsada de alta energia. [dissertação]. São Paulo: Faculdade de Medicina, Universidade de São Paulo; 2004.

Dover JS, Margolis RJ, Polla LL, Watanabe S, Hruza GJ, Parrish JÁ, Anderson RR. Pigmented guinea pig skin irradiated with Q-switched ruby laser pulses. Arch Dermatol. 1989;125:43-9.

Duarte AA. Poiquilodermia de Civatte: estudo histopatológico e possível associação com coronariopatias. [tese]. São Paulo: Faculdade de Medicina, Universidade de São Paulo; 1996.

Even-Paz Z, Sagher F. Cutis punctata linearis colli: stippled skin. Dermatologica. 1963;126:1-12. 
Fiskerstrand EJ, Svaasand LO, Kopstad G, Dalaker M, Norvang LT, Volden G. Laser treatment of port wine stains: therapeutic outcome in relation to morphological parameters. Br J Dermatol. 1996;134:1039-43.

Fitzpatrick TB. The validity and practicality of sun-reactive skin types I through VI. Arch Dermatol. 1988;124:869-71.

Fournier N, Dahan S, Barneon G, Diridollou S, Lagarde JM, Gall Y, Mordon S. Nonablative remodeling: clinical, histologic, ultrasound imaging, and profilometric evaluation of a $1540 \mathrm{~nm}$ Er:Glass laser. Dermatol Surg. $2001 ; 27: 799-806$.

Geronemus R. Poikiloderma of Civatte. Arch Dermatol. 1990;126:547-8.

Geronemus RG, Kauvar ANB, Quintana A. Successful treatment of poikiloderma of Civatte utilizing the pulsed dye laser. Lasers Surg Med. 1999;(Suppl 11):62

Goldberg DJ. Full-face dermal remodeling with a $1320 \mathrm{~nm}$ Nd:YAG laser. Dermatol Surg. 2000;26:915-8.

Goldberg DJ, Silapunt S. Histologic evaluation of a Q-switched Nd:YAG laser in the nonablative treatment of wrinkles. Dermatol Surg. 2001;27:744-6. 
Goldberg LH, Altman A. Benign skin changes associated with chronic sunlight exposure. Cutis. 1984;34:33-40.

Goldman L, Bauman WE. Laser test treatments for postsolar poikiloderma. Arch Dermatol. 1984;120:578-9.

Goldman MP, Weiss RA. Treatment of poikiloderma of Civatte on the neck with an intense pulsed light source. Plast Reconstr Surg. 2001;107:1376-81.

Graham CH, Rivers J, Kerbel RS, Stankiewicz KS, White WL. Extent of vascularization as a prognostic indicator in thin $(<0.76 \mathrm{~mm})$ malignant melanomas. Am J Pathol. 1994;145:510-4.

Graham R. What is poikiloderma of Civatte? Practitioner.1989;233:1210.

Graham Little EG. Poikilodermie - Civatte. $\mathrm{Br} J$ Dermatol Syphil. $1928 ; 40: 231-41$

Haywood RM, Monk BE. Treatment of poikiloderma of Civatte with the pulsed dye laser: a series of seven cases. J Cutan Laser Ther. 1999;1:45-8.

Hernández-Pérez E, Colombo-Charrier E, Valencia-Ibiett E. Intense pulsed light in the treatment of striae distensae. Dermatol Surg. 2002a;28:1124-30. 
Hernández-Pérez E, Ibiett EV. Gross and microscopic findings in patients submitted to nonablative full-face resurfacing using intense pulsed light: a preliminary study. Dermatol Surg. 2002b;28:651-5.

Hsu SM, Raine L, Fanger H. Use of avidin-biotin-peroxidade complex (ABC) in immunoperoxidase techniches: a comparison between $A B C$ and unlabeled antibody (PAP) procedures. J Histochem Cytochem. 1981;29:577-80.

Jacobi E. Poikilodermia atrophicans vascularis. Ikonogr Dermatol. 1908;3:95-8.

Jacoby WD. Juxta-clavicular beaded lines [letter]. Arch Dermatol. 1976;112:1034-5

Katoulis AC, Stavrianeas NG, Georgala S, Katsarou-Katsari A, KoumantakiMathioudaki E, Antoniou C, Stratigos JD. Familial cases of poikiloderma of Civatte: genetic implications in its pathogenesis? Clin Exp Dermatol. $1999 ; 24: 385-7$

Katoulis AC, Stavrianeas NG, Katsarou A, Antoniou C, Georgala S, Rigopoulos D, Koumantaki E, Avgerinou G, Katsambas AD. Evaluation of the role of contact sensitization and photosensitivity in the pathogenesis of poikiloderma of Civatte. Br J Dermatol. 2002;147:493-7. 
Katoulis AC, Stavrianeas NG, Vamvasakis E, Koumantaki-Mathioudaki E, Katoulis A, Katsambas AD. Poikiloderma of Civatte: an electron microscopy study. J Eur Acad Dermatol Venereol. 2001;15(Suppl 2):235.

Landis JR, Kock GG. The measurement of observer agreement for contrasts among multinomial populations. Biometrics. 1977;33:159-74.

Lautenschlager S, Itin $\mathrm{PH}$. Reticulate, patchy and mottled pigmentation of the neck. Acquired forms. Dermatology. 1998;197:291-6.

Leder M. Erythrosis interfollicularis colli. Dermatologica. 1944;89:132-8.

Lee ES, Kim JH, Im S, Lee KB, Sohn S, Kang WH. Application of computerized image analysis in pigmentary skin diseases. Int $J$ Dermatol. $2001 ; 40: 45-9$

Lee MWC. Combination 532-nm and 1064-nm lasers for noninvasive skin rejuvenation and toning. Arch Dermatol. 2003;139:1265-76.

Lee $\mathrm{Y}$, Hwang K. Skin thickness of Korean adults. Surg Radiol Anat. 2002;24:183-9.

Masson P. Carcinoids and nerve hiperplasia of the appendicular mucosa. Am J Pathol. 1928;4:181. 
McCoy S, Grevelink JM. Results of patients treated for poikiloderma of Civatte with the flashlamp-pumped pulsed dye laser. Lasers Surg Med. 1998;(Suppl 10):44-5.

Mehregan A, Hashimoto K, Mehregan D, Mehregan D. Pinkus' guide to dermatohistopathology. 6th ed. Englewood Cliffs: Prentice-Hall International Inc.; 1995. Chap. 9, p.131-44: Lichenoid and poikilodermatous tissue reactions.

Menaker GM, Wrone DA, Willians RM, Moy RL. Treatment of facial rhytids with a nonablative laser: a clinical and histologic study. Dermatol Surg. $1999 ; 25: 440-4$

Menaker MA. [Comentário de: Trelles MA, Allones I, Luna R. Facial rejuvenation with a nonablative $1320 \mathrm{~nm} \mathrm{Nd:YAG} \mathrm{laser:} \mathrm{a} \mathrm{preliminary} \mathrm{clinical}$ and histologic evaluation. Dermatol Surg. 2001;27:111-6]

Nakayama H, Harada R, Toda M. Pigmented cosmetic dermatitis. Int J Dermatol. 1976;15:673-5.

Negishi K, Wakamatsu S, Kushikata N, Tezuka Y, Kotani Y, Shiba K. Fullface photorejuvenation of photodamaged skin by intense pulsed light with integrated contact cooling: initial experiences in asian patients. Lasers Surg Med. 2002;30:298-305 
Pierini LE, Bosq P. Maladie de Civatte. Ann Dermatol Syph. 1938;9:381-420.

Prieto VG, Sadick NS, Lloreta J, Nicholson J, Shea CR. Effects of intense pulsed light on sun-damaged human skin, routine, and ultrastructural analysis. Lasers Surg Med. 2002;30:82-5.

Raulin C, Greve B, Grema H. IPL technology: a review. Lasers Surg Med. 2003;32:78-87.

Raulin C, Schroeter C, Maushagen-Schnaas E. Einsatzgebiete einer hochenergetischen Blitzlampe (PhotoDerm VL). Hautarzt. 1997a;48:886-93.

Raulin C, Schroeter CA, Weiss RA, Keiner M, Werner S. Treatment of portwine stains with a noncoherent pulsed light source. Arch Dermatol. 1999;135:679-83.

Raulin C, Weiss RA, Schönermark MP. Treatment of essential telangiectasias with an intense pulsed light source (PhotoDerm VL). Dermatol Surg. 1997b;23:941-6.

Riehl G. Melanodermatitiden. Wien Klin Wochenschr. 1917;30:780-7.

Sadick NS. Update on non-ablative light therapy for rejuvenation: a review. Lasers Surg Med. 2003;32:120-8. 
Sahoo B, Kumar B. Rôle of methylchloroisothiazolinone/methylisothiazolinone (Kathon® CG) in poikiloderma of Civatte. Contact Dermatitis. 2001;44:249.

Schroeter CA, Neumann HAM. An intense light source. The PhotoDerm VLflashlamp as a new treatment possibility for vascular skin lesions. Dermatol Surg. 1998;24:743-8.

Serrano G, Pujol C, Cuadra J, Gallo S, Aliaga A. Riehl's melanosis: pigmented contact dermatitis caused by fragrances. J Am Acad Dermatol. 1989;21:1057-60.

Siegel S, Castellan Jr NJ. Non-parametric statistics. 2nd ed. Nova York: McGraw-Hill, 1988. p.339

Sliney DH. Optical radiation safety of medical light sources. Phys Med Biol. 1997;42:981-96.

Trelles MA, Allones I, Luna R. Facial rejuvenation with a nonablative 1320 nm Nd:YAG laser: a preliminary clinical and histologic evaluation. Dermatol Surg. 2001;27:111-6.

Weiss RA, Dover JS. Laser surgery of leg veins. Dermatol Clin. 2002;20:19-36. 
Weiss RA, Goldman MP, Weiss MA. Treatment of poiquiloderma of Civatte with an intense pulsed light source. Dermatol Surg. 2000;26:823-8.

Weiss RA, Weiss MA, Beasley KL. Rejuvenation of photoaged skin: 5 years results with intense pulsed light of the face, neck and chest. Dermatol Surg.2002;28:1115-9.

Wheeland RG, Applebaum J. Flashlamp-pumped pulsed dye laser therapy for poikiloderma of Civatte. J Dermatol Surg Oncol. 1990;16:12-6.

Zaynoun ST, Aftimos BA, Tenekjian KK, Kurban AK. Berloque dermatitis - a continuing cosmetic problem. Contact dermatitis. 1981;7:111-6.

Zelickson B, Kist D. Effect of pulse dye laser and intense pulsed light source on the dermal extracellular matrix remodeling. Lasers Surg Med. 2000;(Suppl 12):17. 